\title{
Intertextuality, Narrativity and Tradition: 8 Brazilian Piano Sonatas
}

\author{
Intertextualidade, Narratividade e Tradição: \\ 8 Sonatas Brasileiras para Piano
}

\author{
Cristina Capparelli Gerling \\ Universidade Federal do Rio Grande do Sul - UFRGS \\ ccgerling@gmail.com
}

Abstract: Based on theories of intertextuality and narrativity as well as historical and social contextualization, the present paper discusses how eight piano sonatas written between 1950 and 1967 by César Guerra-Peixe (1914-1993), Eunice Catunda (1915-1990), Claudio Santoro (1919-1989), Esther Scliar (1926-1978) and Edino Krieger (1928) respectively, formed a new corpus of Brazilian concert music thoroughly grounded on neoclassical formal principles. Permeated with the highest level of pianistic virtuosity these eight works paved the way for a host of future works written by composers older and younger. The main argument is developed through the approximation between shared characteristics such as the prominence given to passages in unison found within the sonatas initial thematic statements and the utterances delivered by dramatic types, be they heroic or comic characters.

Keywords: Piano Sonatas; Intertextuality; Narrativity; Unison.

Resumo: Tendo por base teorias da intertextualidade, da narratividade bem como uma contextualização histórica e social, o presente artigo discute como oito sonatas para piano escritas entre 1950 e 1967 por César Guerra-Peixe (1914-1993), Eunice Catunda (1915-1990), Claudio Santoro (1919-1989), Esther Scliar (1926-1978) e Edino Krieger (1928) respectivamente, contribuíram para formar um novo corpus na música brasileira de concerto alicerçada nos princípios formais do neoclassicismo. Impregnadas com elevados níveis de virtuosismo pianístico, as oito sonatas deram início à escrita de sonatas produzidas por compositores de gerações anteriores e posteriores. $\mathrm{O}$ argumento principal faz uma aproximação entre as características compartilhadas mais proeminentes, em especial ao papel do uníssono no complexo temático inicial de cada sonata e a apresentação de tipos dramáticos, sejam eles de caráter heroico ou cômico.

Palavras-chave: sonatas para piano; intertextualidade; narratividade; uníssono. 
GERLING, Cristina Capparelli. 2016. Intertextuality, Narrativity and Tradition: 8 Brazilian Piano Sonatas. MUSICA THEORICA. Salvador: TeMA, 201609, p. 1-36.

\section{1 - Introduction}

"...the response to culture is, like myth, a revolutionary act of consciousness." 1

An assessment of the Latin American piano repertoire organized into standard categories of Sonatinas, Sonatas, Themes and Variations and so forth ${ }^{2}$ reveals that up to the 1950's, there are very few Brazilian major sonatas for piano solo ${ }^{3}$. Considering that Villa-Lobos wrote none, I was able to locate two works, one by Francisco Mignone (1941) and one by Lorenzo Fernandez (1948). Contrasting with the production of Brazilian composers, from the late 1920's Carlos Chavez in Mexico and the Argentineans, quite a few of them associated with Grupo Renovacionn, ${ }^{4}$ produced a number of works bearing this title. And then, as if by some kind of tacit agreement, from the 1950's onwards a significant number of Brazilian Piano Sonatas start being composed at a steady pace.

\begin{tabular}{|c|c|c|c|}
\hline Composer & Abbreviation & Title & Year \\
\hline César Guerra-Peixe & GP 1 & Sonata $\mathrm{n}^{\circ} 1$ para piano & 1950 \\
\hline Edino Krieger & EK 1 & Sonata $\mathrm{n}^{\circ} 1$ para piano & 1953 \\
\hline Claudio Santoro & CS 3 & Sonata $\mathrm{n}^{\circ} 3$ & 1955 \\
\hline Edino Krieger & EK 2 & Sonata $n^{\circ} 2$ para piano & 1956 \\
\hline Claudio Santoro & CS 4 & 4. Klavier Sonate (Fantasia) & 1957 \\
\hline Eunice Catunda & EC & Sonata de Louvação & 1958 \\
\hline Ester Scliar & ES & Sonata para piano & 1960 \\
\hline César Guerra-Peixe & GP 2 & Sonata $\mathrm{n}^{\circ} 2$ (para piano) & 1967 \\
\hline
\end{tabular}

Figure 1: Brazilian Piano Sonatas written between 1950 and 1967

I wish to express my gratitude to Stefanie Freitas, Fredi Gerling and Ilza Nogueira for their invaluable commentaries and observations.

${ }^{1}$ Frye, Northrop. 1957. Anatomy of Criticism. Princeton University Press, p. 344.

2 www.ufrgs.br/gppi

${ }^{3}$ Alberto Nepomuceno wrote a Piano Sonata in 1894 while still a student in Europe. The work is available through Goldberg Editions. Santoro's Piano First and Second Piano Sonatas as well as the Sonata from 1942 are much shorter twelve-tone works.

${ }^{4}$ Composers belonging to Grupo Renovación founded in 1929 were the three Castro brothers, José María, Washington and Juan José, in addition to Gilardo Gilardi, Juan Carlos Paz, Jacobo Ficher and Luis Gianneo. There is an expressive number of piano sonatas written by these composers. 
Collectively, these eight works demonstrate how César Guerra-Peixe (1914-1993), Eunice Catunda ${ }^{5}$ (1915-1990), Claudio Santoro (1919-1989), Esther Scliar (1926-1978) and Edino Krieger (1928) turned away from their previously preferred style of composing shorter works with twelve-tone materials and produced instead a significant number of longer works aligned with the musical tenets of previous generations. The more I play the sonatas, the more I see them as an unified endeavor, part of a common project originating from wide-ranging circumstances, one of them being the availability of Brazilian pianists active at the time ${ }^{6}$, pianists that could and did make these composers better known to the world of concert music.

These eight sonatas composed between 1950 and 1967 integrate the grand tradition of piano music, challenging to learn, fully worth the results. As mature compositions written to integrate the canon, it is hardly coincidental that these work share common features, the most observable being the virtuoso pianistic writing integrated with fully developed sonata structures. Concerning this last aspect, this paper aims at complementing studies dedicated to particular works and/or groups of works of an individual composer, correspondences between composers and musicologists, as well as the scholarly texts dedicated to the study of the Musica Viva Group ${ }^{7}$.

My analytical views for this particular repertoire certainly involved extensive readings but the interpretative ideas I'm proposing were distilled during many rewarding hours at the piano, both as a teacher and, above all as a pianist. My approach departs from the initial idea that introduces each one of the works because the nature of the music- as performance- demands an

\footnotetext{
${ }^{5}$ Eunice Monte Belo adopted her husband Omar Catunda's last name. After 1964, she changed the spelling to Katunda. Considering that the Sonata was written in 1958, I've opted to keep the original spelling of her name.

${ }^{6}$ Brazilian pianists Heitor Alimonda (1922-2002), Arnaldo Estrella (1908-1980), Ana Stella Schic (1925-2008) and Homero Magalhães (1924-1998), at that time also active in Europe, recorded and performed these works thus legitimizing them on a par with other sonatas from the international piano repertoire. CS3 and GP1 are dedicated to Alimonda and his wife Jeanette Herzog.

${ }^{7}$ Godoy, Monica. 1994. "Claudio Santoro: Overview of his Piano Works and Analysis of the Fourth Piano Sonata". Doctoral Dissertation, Boston University.

Holanda, Joana Cunha de. 2006. "Eunice Catunda (1915-1990) e Esther Scliar (1926-1978): Trajetórias Individuais e Análise de "Sonata de Louvação" (1960) e "Sonata para Piano" (1961)". Doctoral Dissertation, UFRGS.

Vieira, Bruna Maria de Lima. 2005. "Sonata n.1 para Piano e Divertimento para Cordas de Edino Krieger : um Estudo Comparativo". Master's Thesis, UFRGS.

Livero de Souza, Iracele V. A. 2006. “Louvação a Eunice: um Estudo de Análise das Obras para Piano de Eunice Catunda". Doctoral Dissertation, UNICAMP.

Botelho, Flávia Pereira. 2013. "Guerra-Peixe e a Busca pela Renovação do Nacionalismo Musical: Reflexos na Obra para Piano". Doctoral Dissertation, USP.
} 
integration of all elements while in flux and not a static segmentation of its component parts.

\section{2 - The World Divided}

As part of my quest to contextualize these works, I evoke some of the historical circumstances surrounding their compositions. As the World War II divided the twentieth century and its consequences were still intense in the Northern Hemisphere, throughout the 1940's and, amongst a larger contingent of disciples, five aspiring composers distinguished themselves by producing a steady supply of shorter works based mainly, but not exclusively, on the use of twelve-tone techniques. Gathered around H.J. Koellreutter (1915-2005), according to Kater (2001a) these young Brazilian composers were assiduously learning the craft of composition. Collectively known as Musica Viva Group ${ }^{8}$ they worked enthusiastically for the diffusion of new and progressive music played in concerts, recitals and radio broadcasts.

As a teacher, Koellreutter was broad minded and above all, he generously allowed his students to partake from his books, recordings and scores, then rare commodities in these tropical lands. Among these materials, Paul Hindemith's The Craft of Musical Composition (1937) was one of the most valued resources.

In the preface to this compositional guide closely read and exercised by Koellreutter's students, Hindemith acknowledges debts to composers from Palestrina, to Fux, to Wagner, and he certainly places J. S. Bach on the highest pedestal. As he admonishes on the importance of thoroughly knowing the works of predecessors and contemporaries, he also cautions composition teachers to "follow at a distance, to mint into current coin the wealth which the composers have mined." He persists on the subject as he describes the role of the composition teacher as someone who "must exercise a guiding and calming influence on the young musician who is in the throes of experiment; he must steer him between the Scylla of blind worship of the past and the Charybdis of idolatry of the present". This last phrase sums up the conflicts composers were facing, whether to stay close to tradition - that is the modernist nationalist music of Brazil - or to continue venturing into dodecaphonic innovations.

Neither too progressive nor too conservative, from the early 1940's American composer Aaron Copland, acting as a cultural ambassador, undertook a series of visits to Latin American countries. It is opportune to recall that during his visits to Brazil, Copland had played his own Piano Sonata (1939-41) even

\footnotetext{
${ }^{8}$ Egg, André. 2005. O Grupo Música Viva e o Nacionalismo Musical. Anais do III Fórum de Pesquisa Científica em Arte, Escola de Música e Belas Artes do Paraná. Curitiba, p. 60-70.
} 
before the American premiere in New York ${ }^{9}$. It is somewhat intriguing to find out that while Villa-Lobos, then at the pinnacle of his career, was quite eager to gain Copland's respect and friendship the American composer was quite ambivalent on his appraisal of his Brazilian older colleague. In contrast, Copland extolled Camargo Guarnieri's music, in particular his Third Sonatina (1937) combining folk material and a decisively personal style. He commented on Guarnieri's "healthy emotional expression and warmth and imagination were touched by a sensibility that is profoundly Brazilian"10.

It is worthy of note that, at this like no other time, Villa-Lobos, Guarnieri, Mignone and Fernandez received official invitations to have their music performed by major American orchestras ${ }^{11}$. Likewise, their piano music, particularly the repertoire accessible to beginners and intermediate piano students, was published in the US. While Copland was full of praise for neoclassical frames and contrapuntal elaborations, he also commented that many of South American young composers could not detach themselves from Debussy and Ravel. In fact, he had little to say about young Brazilians. He did single out Claudio Santoro (1919-1989) as talented and, without naming anyone in particular, described young Brazilian composers as shallow. ${ }^{12}$

As the 1940's progressed, Koellreutter's students started searching for more permanent positions as well as for career alternatives including leaving their native country to study abroad. As is well known, following the end of the Second World War won by two major superpowers, respectively communist USSR and capitalist USA- both determined to phase out Nazi-Fascism, the planet earth was split into two conflicting ideologies. This split lead to an insidious state of permanent tensions. As part of the effort against the spread of communism in Europe, as early as 1946 the US fomented the creation of the festivals in Europe dedicated to the musical vanguard ${ }^{13}$ that attracted as planned, worldwide recognition and visibility. Brazil, albeit reluctantly, was maneuvered towards the American capitalism sphere of influence with the consequent official rejection of communist ideology. The Brazilian communist party was outlawed in 1947.

As noted by Skidmore, around 1949, the international directives for the Cold War had been fully exposed and the American government was exerting pressure on Brazil and all of Latin American for joining sides with USA instead

\footnotetext{
9 Tacuchian, Fátima Granja. 1998. “Panamericanismo, Propaganda e Música Erudita: Estados Unidos e Brasil (1939-1948)". Doctoral Dissertation, USP, p. 128.

${ }^{10}$ Copland, Aaron. 1942. The Composers of South America. Modern Music, p. 79-80.

${ }^{11}$ Haskins, John. 1957 (Dec.). Pan Americanism in Music. Notes, XV, No.1, p. 43-49.

12 Pollack, Howard. 1999. Aaron Copland: The Life and Work of an Uncommon Man. New York: Henry Holt and Co, p. 254-260.

${ }^{13}$ Thomas, Ernst \& Schlüter, Wilhelm. 2001. "Darmstadt". The New Grove Dictionary of Music and Musicians, second edition, Stanley Sadie and John Tyrrell, eds., London: Macmillan Publishers.
} 
of USSR. Continuing the policies established in the early 40's and trying to make this injunction more palatable, support from USA poured in the form of financial aid, including opportunities for artists to travel to USA and to be well received at Festivals, Seminars and other similar venues. Two composers, Claudio Santoro and Edino Krieger won composition prizes accompanied by grants to study in the United States. Santoro's affiliation with the communist party barred his entrance while Krieger could and did study at the Berkshire Festival in Tanglewood and later at the Juilliard School (NY, USA). Santoro was able to go to France where he studied with Mme. Boulanger among other eminent musicians.

In the meantime, a group of Koellreutter's disciples, amongst them Catunda and Scliar, went to Europe in order to study conducting as part of the Venice Biennial Exposition of 1948. The two women already inclined towards all things dodecaphonic, profited from their contacts with artists such as Nono, Maderna, not to mention their opportunity to study with conductor Scherchen, Koellreutter's former mentor. Guerra-Peixe, consciously avoiding being attracted to Villa-Lobos orbit ${ }^{14}$, moved far away from his native state, Rio de Janeiro. He found work at a radio station in the Brazilian Northeast, settled at the city of Recife and shortly after immersed himself into the study of local folklore.

At this time, Moscow did not lag behind in trying to attract artists to the communist fold by setting up congresses ${ }^{15}$ such as the Second International Congress of Composers and Music Critics held in Prague in 1948 and attended by Claudio Santoro with lasting effect. While eastern Europeans were subjugated under the strictures of the Zhdanov Doctrine ${ }^{16}$ reedited during the Prague Congress, western Europeans gathered in Darmstadt wrote (ultra) progressive dodecaphonic and serial music. The profound ideological divide between East and West only increased as its foremost superpowers kept on competing to win the allegiance of promising artists.

On the Soviet side of the world, Prokofiev's War Sonatas were given prominence, most of all his Bb Piano Seventh Sonata (1939-42) dubbed as the Stalingrad Sonata. Prokofiev's music was written not only in accordance with the directives proclaimed by the socialist regime but it may in fact have inspired the

\footnotetext{
${ }^{14}$ Faria, Antonio Guerreiro de. 2000. Guerra-Peixe e a Estilização do Folclore. LAMR, XXI, n 2, p. 169-189.

${ }^{15}$ Saunders, Frances Stonor. 2000. Who Paid the Piper? CIA and the Cultural Cold War. London: Granta Books.

${ }^{16}$ https://en.wikipedia.org/wiki/Andrei_Zhdanov. Accessed: 2-1-2016.
} 
commands issued at the Prague Congress ${ }^{17}$. These commands imposed a series of restrictions as to how composers should avoid "formalism", "subjectivism" and should strive to reach "universals". Composers were instructed to produce music objectively based on folk material expertly handled. Needless to say, the doctrine that came to be known as Zhdanovism ${ }^{18}$ determined a course of action whereby composers should produce social realistic music in order to be fully accepted as socially useful artists.

No matter how much money the US poured into European Festivals dedicated to musical vanguard ${ }^{19}$, American composers were harvesting neoclassical compositions at a steady rate, several piano sonatas included in this tally ${ }^{20}$. Against common beliefs, Straus argues that during the early postwar period "serialism never came close to dominating any aspect of American musical life - indeed, that it remained a visible but effectively marginal phenomenon throughout the period" 21 .

It is fair to state that during the early 1950's, the time four of the five composers came back to their native Brazil and were trying to settle into professional activities, music composed under the aegis of the two superpowers can be justly described as conservative. While Socialist Realism was mandatory in communist world, few western composers managed to escape the pull of Neoclassicism ${ }^{22}$. In the years following the end of WWII, composers on both sides of the North Atlantic produced a significant number of piano sonatas modeled after the prevailing neoclassical fashion. Few if any, however, achieved the recognition bestowed upon Alberto Ginastera' ${ }^{23}$ four movement First Piano Sonata written in 1952. This work resulted from a well-publicized commission as part of the post war effort to attract Latin American artists to the American fold and to protect them from the communist menace.

\footnotetext{
${ }^{17}$ Second International Congress of Composers and Music Critics held in Prague (the capital of Czechoslovakia) in 1948, see Hartmann, Ernesto. 2010a. Claudio Santoro e o II Congresso de Compositores Progressistas de Praga. Anais do I SIMPOM, p. 460-468.

${ }^{18}$ Hartmann, Ernesto. 2010b. “Estética Musical e Realismo Socialista em Obras Nacionalistas para Piano de Claudio Santoro: Janelas Hermenêuticas." Doctoral Dissertation, UNIRIO.

19 Mathews, Jane de Hart. 1976 (Oct.). "Art and Politics in Cold War America". The American Historical Review, Vol. 81, No. 4, p. 762-787.

${ }^{20}$ Masterson, Sarah. 2011. "Approaches to Sonata Form in Mid-Twentieth-Century American Piano Sonatas", Doctoral Dissertation. University of Connecticut.

${ }^{21}$ Straus, Joseph N. 1999 (Autumn). The Myth of Serial Tyranny in the 1950s and 1960s. The Musical Quarterly, Vol. 83, No. 3, p. 301-343.

${ }^{22}$ Hyde, Martha M. 1996 (Autumn). Neoclassic and Anachronistic Impulses in TwentiethCentury Music. Music Theory Spectrum, Vol. 18, No. 2, p. 200-235.

${ }^{23}$ Ginastera lost his post as Director of the Conservatorio de la Provincia of Buenos Aires because he refused to rename the institution after Peron's wife, Eva Duarte recently deceased.
} 
Meanwhile, Brazil - the Slumbering Giant ${ }^{24}$ - was awaking from one of his naps. Despite some heavy tilting of the democratic boat, between 1950 and 1961 Brazilians elected three presidents, one of them governed the full five-year term while inducting an effective program of industrialization. The idea of a viable future dominated the country's mood spilling over all manner of artistic manifestations. This period coincides with the emergence of new artistic manifestations such as Bossa Nova, Cinema Novo [engaged cinema], the building of Brasília with its innovative architecture and the shaping of the modern face of the country. Artistic production, part and parcel of this turn to the national and the popular as a cultural project, approximated left and right political tendencies ${ }^{25}$.

The inception of Brazilian radio, TV and movies as well as the expanding recording industry from the 1950's onwards provided occupation to Brazilian composers eager to find meaningful work. While Guerra-Peixe and Krieger were able to secure stable positions, Santoro struggled without any enduring success until 1957, the year he went back to Eastern Europe. Catunda, a permanent presence on radio programs, also spent a great deal of her time involved with Afro-Brazilian culture and religion and traveled frequently to Salvador, while by 1956, Scliar had settled permanently at Rio de Janeiro. At different times and capacities, during the time these eight sonatas were written, all five composers provided music for radio, television and cinema including arranging for radio and TV shows, conducting ensembles for these media and writing music for children's stories as well as incidental music for movies. In addition to mentioning events and facts that may have impacted, to a greater or to a lesser extent, the composition of these works, it is also known that all five were friends. As friends do, they admired each other's productions and they discussed their political and their musical inclinations, including their current compositions. Guerra-Peixe, Santoro and Krieger were trained as violinists; Scliar and Catunda were trained as pianists. Scliar's highly sensitive personality prevented her from being a concert pianist while Catunda was recognized first and foremost as an extraordinary performer. Nevertheless, each one of the piano sonatas, despite shared traits, is a display of individuality and creative power.

Starting with Guerra-Peixe rigorously formed Sonata $\mathrm{n}^{\mathrm{0}} 1$ for piano (1950), the scale tilted heavily towards Scylla. It is only fair to say that these composers were fully cognizant of the approximation to the music of Villa-Lobos as well as to the practices of Guarnieri, Mignone and Fernandez, some of the most

\footnotetext{
24 The lyrics of the Brazilian National Anthem refer to Brazil as a Giant "eternally lying on a splendid crib".

25 Napolitano, Marcos. 2014. Esquerdas, Política e Cultura no Brasil (1950-1970): um Balanço Historiográfico. Revista do Instituto de Estudos Brasileiros, n. 58, p. 35-50.
} 
prestigious Brazilian composers identified with the nationalistic modernistic style. As seen in their correspondence ${ }^{26}$ and despite complaints, sorrows, boastings, hard feelings and other displays of candid opinions, these composers were fully intent not only in joining the 'old' guard but to supplant them as legitimate successors.

\section{3 - Sonata as Myth}

Noted scholar William S. Newman pairs the "first real flowering of the solo keyboard sonatas" with the culture history of the XVIII c. European Enlightenment and "with its pursuit of freedom, reason and humanitarianism" 27. This very encompassing view of the sonata applies to an extent much greater than expected to the eight works discussed in this paper. By and large, coherence is achieved by intertextual resources- the use of common elaborative procedures grounded on the traditions and practices of previous generations and that of their contemporaries aligned with a strong narrative content as displayed in salient topics. Given the balance between intertextual, that is shared elements and narrative distinctiveness, I see these imposing structures as an integral component in the forging of an identity for the Brazilian concert music repertoire. Collectively, they stand for the first flowering of Brazilian sonatas during a time of heated discussion about the political destinies of the country and its people. Freedom, reason and human rights were not empty words, each one of the composers had to take sides and consider their political options during a time charged with political turmoil. Their individual lives followed different courses but, at this particular point in time, all five threaded on a musical common ground. They resolutely adopted neoclassical archetypes for the writing of their piano sonatas as well as their extended chamber music production.

Of all the stories told with sounds, a Sonata is the most mythological of them all in the sense that, from the XIX century, Sonatas were elevated to a sacred genre, a hypertext to be conquered and surpassed by composers aspiring recognition. The desire to supersede predecessors causes an increase in sophistication and, musical analysts agree that sonata writing has been a vehicle for the display of individuality within highly developed and circumscribed systems of musical thought. Ever since instrumental music rose from its secondary role, sonatas, as a broad category, have set the rules by which coetaneous musical values are defined. Therefore, it is useful to remember that

\footnotetext{
26 Barros, Frederico Machado de. 2013. “César Guerra-Peixe: a Modernidade em Busca de uma Tradição". Doctoral Dissertation, Universidade de São Paulo.

27 Newman, W. S. 1972. The Sonata in the Classic Era. New York: Norton, p. 3.
} 
during the latter part of the XVIII c. the composition of sonatas of varied shapes was a most common occurrence, whereas in the XIX c. this production slowed down as the proportions and level of complexity of the works increased. In addition, during the time sonatas were intensely produced for immediate performance and enjoyment, their compositional methods were hardly ever discussed in print. According to Bond"28, "a broad range of eighteenth-century theorists and aestheticians considered an individual work of instrumental music to be a kind of wordless oration whose purpose was to move the listener". More often than not, an oration gains momentum from an initial crucial statement. As an act of persuasion, "generative forces" 29 originating at the very beginning of the work empower both, oration and orator.

As seen in Fig. 2, Fernandez's Sonata Breve was the last piece written before the composer's untimely death. Most importantly, some of its features are replicated in the sonatas of his successors.

Some of the most prominent features found in Fernandez's Allegro Energico are the persistent reiteration of seminal motives, short unison figurations followed by passages with octave doublings, registral displacement, parallel chord motion consisting of extended tertian, quartal, and quintal sonorities as well as the emphasis placed on stringent dissonant sonorities caused by the clash of seconds. This work also displays a high level of contrast between ideas pointing to an avowed adoption of a neoclassical style grounded on clear-cut and intelligible (for the sake of the listener) formal structures. These characteristics are part and parcel of the music of Hindemith, Stravinsky, Bartók and, as previously mentioned, many if not all of these traits can also be found in the music of contemporary North and South American composers, for instance Copland's and Ginastera's Piano Sonatas. Speaking of models and predecessors, the final paragraph of Hindemith's introduction ${ }^{30}$ is based on some of the most significant claims of intertextual theory:

\footnotetext{
"We cannot conjure up past times, although every man must come to some agreement with himself about the bases of his work. But that our consideration of tonal materials and its application by all who may concern themselves with it may catch a kindling spark from the spirit of the old masters is the hope from which this work springs." (Hindemith, 1937).
}

28 Bonds, Mark Evan. 1991. Wordless Rhetoric, Musical Form and the Metaphor of the Oration. Cambridge: Harvard University Press.

${ }^{29}$ Bonds, op. cit., p. 7.

${ }^{30}$ Hindemith, op. cit., p. 13. 


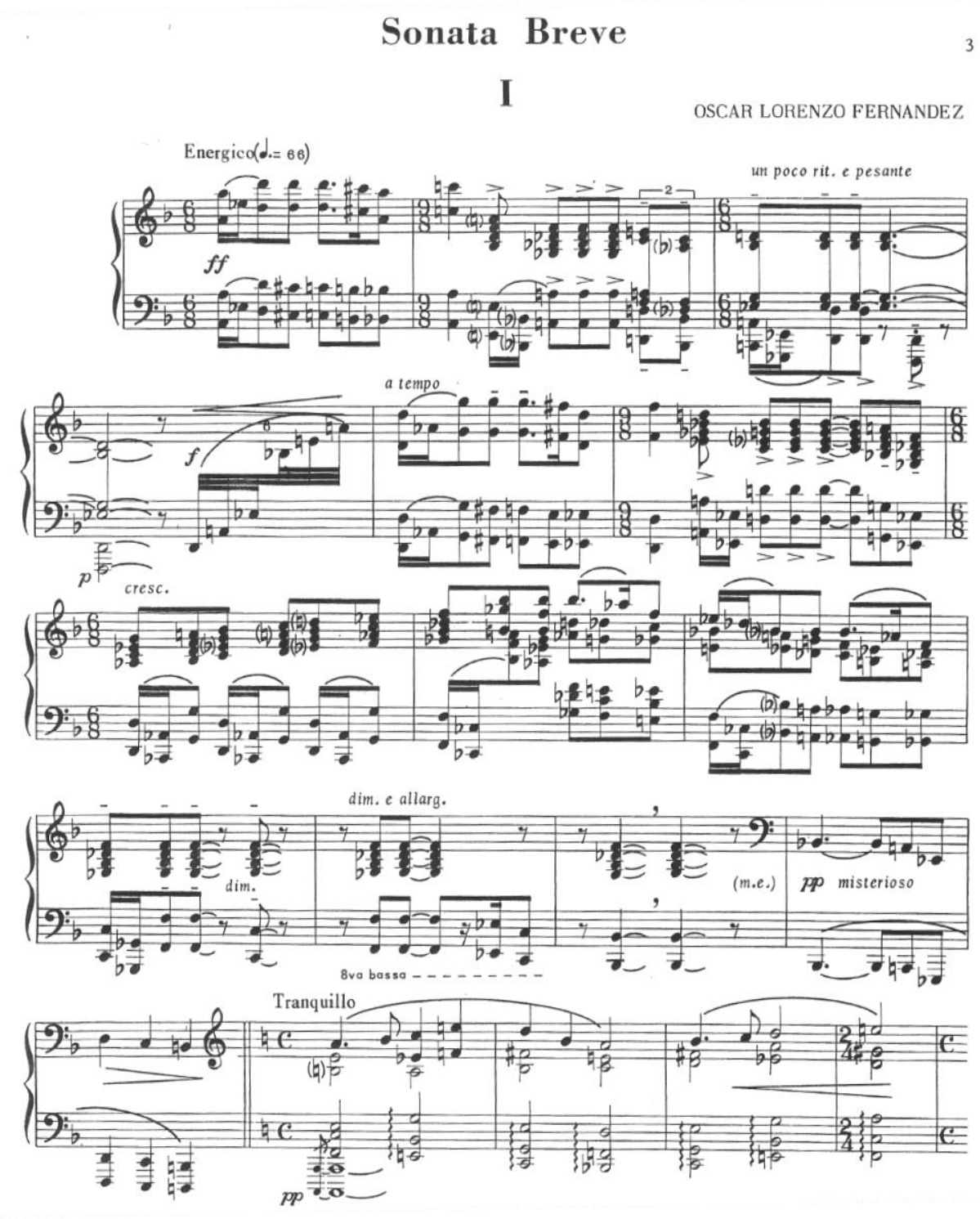

Figure 2: Lorenzo Fernandez' Sonata Breve [mm. 1-18]

Hindemith's introduction which predates Bloom's theories of anxiety and influence ${ }^{31}$ by at least thirty years, not only accepts the inescapability of the centrifugal force of influence with the consequential intertextual manifestations ${ }^{32}$, it provides the basic laws for borrowing, and transforming shared ideas into distinctive musical composition.

\footnotetext{
${ }^{31}$ Bloom, Harold. 1975. A Map of Misreading. New York: Oxford University Press; Juvan, Marko. 2008. "Towards a History of Intertextuality in Literary and Cultural Studies". CLCWeb: Comparative Literature and Culture 10.3: http://docs.lib.purdue.edu/clcweb/vol10/iss3/1 ${ }^{32}$ https://en.wikipedia.org/wiki/Julia_Kristeva. Accessed Feb. 9, 2016.
} 
My study of these eight works is supported by intertextual theory here summoned as a pervasive and inescapable phenomenon, understood as result of high caliber exchange of ideas between mature composers dialoguing with their predecessors so that their works could be part of the canon. To make it very clear, there is no borrowing of raw materials, there is sharing of common beliefs expressed through the highest musical means- the sonata structure as a hypertext. These eight piano sonatas (Fig. 1) point to the fact that composers aimed not only at succeeding on the terms of their predecessors but, most importantly, at supplanting them. Success depends on improving proven models ${ }^{33}$. As part of my analytical considerations, I call attention to the fact that, just as in previous epochs, each one of the eight works here discussed, enters into an intense dialogue with all other works bearing this title, past, present and future.

At this point, I remind the reader that the emergence of Brazilian TV and film industry from the 1950's onwards brought about a proliferation of sharply characterized Brazilian human types ${ }^{34}$. Cast mostly through strongly focused oppositions between urban and rural, serious and comic, literate and illiterate, smart and dumb, not to mention the perennial noble and deceitful, these characters contributed to influence the way Brazilians see themselves and their country. With this background, I propose to align the means of persuasion, the rhetoric content found throughout the initial thematic presentation of eight piano sonatas written between 1950 and 1967, a period roughly equivalent to the Brazilian Golden Years ${ }^{35}$, with the presentation of a main character that carries the narrative.

From time immemorial, narration and civilization are so entwined as to become impossible to tell apart. Our knowledge of the past, therefore our chance of a future, has been based on great stories, foundational narratives. Main characters, be they heroes and/or villains, carry the action in narratives and all attention is converged towards their deeds. Contemporary as well as timeless stories weave tales of heroes and villains fathered by godlike figures and humble earthly maidens. While heroes are usually bestowed with unusual, even supernatural qualities, villains choose to use their powers unwisely. For the purpose of this brief paper, it suffices to state my contention that, our composers retained paternal-European adherence to the formal aspects while cultivating songs and dance originating from the maternal-Brazilian side of their inheritance.

33 Straus, Joseph. 1990. Remaking the Past. Music Modernism and the Influence of Tonal Tradition. Cambridge: Harvard University Press.

${ }^{34}$ Napolitano, op. cit., p. 3.

35 The expression "Anos Dourados" or "Golden Years" refers to the effervescent mood that prevailed in Brazil during the 1950's. This atmosphere was heightened by the World Cup (1950), the first Latin American TV channel, TV Tupi (1951), and the construction of Brasília (1956-1961). 
Following the end of the war, each one of the five friends and fellow composers turned a deaf ear to the siren's song of dodecaphonism and opted instead to charter their paths closer to the native shores.

\section{4 - Analytical Considerations}

The first movement of each one of the eight works is firmly grounded on sonata structures with contrasting ideas, textures and moods. In addition, seven sonatas are organized as Fast-Slow-Fast three movement works. Catunda's Sonata is a two-movement work. With the possible exception of Scliar's Sonata where the national characteristics are less emphasized, the remaining seven works display at least one movement featuring unequivocal rhythmic and melodic characteristics of Brazilian song and dance, that is, a high degree of allegiance to Brazilian national musical attributes.

Considering primarily the opening idea, that is, the sounds reaching the listener and setting up a powerful first impression, I approach the works relying prominently on unison figurations without overt nationalistic traits, Santoro's Third and Fourth Sonatas (CS 3; CS 4), Scliar's (ES), Catunda's (EC) and Krieger's Second (EK 2), respectively. Then I discuss a work that uses a modified version of unison, a relentless ostinato articulating an avowed nationalistic ritual dance, Guerra-Peixe's Second Sonata (GP 2). The two remaining works, Krieger's First Sonata (EK 1) and Guerra-Peixe's First Sonata (GP 1) respectively, display two facets of nationalism, urban and rural respectively. Unison figurations are dislocated to passages further along within the first idea.

My analytical considerations are based, above all, on my musical interpretation of these first ideas, how the pianist can set up the stage in order to deliver wordless orations. Wordless albeit dramatic and emotional, I present a synoptic view of the eight works organized into three types of initial presentations ${ }^{36}$. On the left side of the figure, five sonatas come to life presenting dramatic heroes powered by unison figurations displaying the kind of determination found in tragic heroes, respectively CS 3, CS 4, ES, EC and EK 2. On the middle column, a work that begins by a long depiction of a ritual dance, GP 2. On the right side, the remaining two sonatas can be appropriately described as comedies as heroes (or rogues) come accompanied by a supporting pair as in EK 1 or a gently retorting antagonist as in GP 1 (see fig.3).

${ }^{36}$ Frye, Northrop. 1957. Anatomy of Criticism. Princeton: Princeton University Press and also Matta, Roberto da. 1983 (4th ed.). Carnavais, Malandros e Heróis - Para uma Sociologia do Dilema Brasileiro. Rio de Janeiro: Zahar. 
GERLING, Cristina Capparelli. 2016. Intertextuality, Narrativity and Tradition: 8 Brazilian Piano Sonatas. MUSICA THEORICA. Salvador: TeMA, 201609, p. 1-36.

\begin{tabular}{|c|c|c|c|}
\hline & CS 3, CS 4, ES, EC, EK 2 & GP 2 & GP 1, EK 1 \\
\hline \multirow{5}{*}{ Character } & Tragedy / Unison & Spectacle / Ostinato & $\begin{array}{l}\text { Comedy / Romance / } \\
\text { Counterpoint }\end{array}$ \\
\hline & Hero stands out & Larger than life & $\begin{array}{l}\text { Hero mingles with/from } \\
\text { daily life }\end{array}$ \\
\hline & $\begin{array}{l}\text { Serious / Exalted / Tragic/ } \\
\text { Determined / Reserved }\end{array}$ & Sublime & $\begin{array}{l}\text { Gallant / Idyllic / Naïve / } \\
\text { Gentle Satire }\end{array}$ \\
\hline & $\begin{array}{l}\text { Music of Experience } \\
\text { [Tradition] }\end{array}$ & Music of trance & Music of Innocence \\
\hline & Order / [Military] Parade & Ritual / Processional & Romance \\
\hline \multirow{2}{*}{$\begin{array}{l}\text { Motivic } \\
\text { Treatment }\end{array}$} & Elaboration & Repetition & Sequencing \\
\hline & $\begin{array}{l}\text { Discontinuous Repetition } \\
\text { \& Elaboration }\end{array}$ & Insistence & $\begin{array}{l}\text { Continuous Sequencing } \\
\text { \& Elaboration }\end{array}$ \\
\hline Type & $\begin{array}{l}\text { Motoric / Forward motion } \\
\text { / March }\end{array}$ & Dance & Lyric / Song \\
\hline Style & $\begin{array}{l}\text { Learned or High Style } \\
\text { stands out / Archaism } \\
\text { International / Paternal } \\
\text { Ascendency }\end{array}$ & $\begin{array}{l}\text { Low Style stands out } \\
\text { / Blatant Nationalism }\end{array}$ & $\begin{array}{l}\text { Learned Style is } \\
\text { downplayed / Hybridism / } \\
\text { National / Maternal } \\
\text { Ascendency }\end{array}$ \\
\hline
\end{tabular}

Figure 3: Synoptic view of initial themes organized into three types of presentations

Maus, while strongly arguing in favor of similarities and equivalences between instrumental music and storytelling, cautions: "an analogy between musical and narrative structures need not depend on an acceptance of conventional descriptions of musical formal patterns" ${ }^{\prime 37}$. As is well known, music is indelibly linked with emotional states primarily triggered by association with affective states $^{38}$. As a pianist, it is my duty, first and foremost, to find the right tone so that I can convey the character ascribed by the composer. The definition of a hero type is not only a legitimate tool but also a means to achieve the kind of sonority that best conveys my interpretation of the composer's text. This seems to be Hatten's point as he points out to the

...evidence for the existence of genres whose interpretation in given movements demands an expressive rather than strictly structural competency. Such "plots" as emerge from these genres may at times suggest a more dramatic than strictly narrative structure, but there is always an implied narrative element in that events unfold through the narrative filters of the composer's persona(s) (Hatten, $1991)^{39}$.

\footnotetext{
${ }^{37}$ Maus, Fred Everett. 1991. Music as Narrative. Indiana Theory Review, XII, p.3-4.

${ }^{38}$ Gerling, Cristina C. \& Santos, Regina A. T. 2015. As Conexões entre Música e Emoção sob Perspectivas Psicológicas, Filosóficas e Estéticas. In: Estudos sobre Motivação e Emoção em Cognição Musical. R. C. Araújo \& D. Ramos, org. UFPR, p. 13-44.

${ }^{39}$ Hatten, Robert. 1991. On Narrativity in Music: Expressive Genres and Levels of Discourse in Beethoven. Indiana Theory Review, XII, p.75.
} 
As previously mentioned, the first movements of the following piano sonatas: CS 3, CS 4, ES, EC and EK 2 begin with statements built primarily on unison figurations showing allegiance to an international style of musical writing distanced from overt national characteristics. The unison has enjoyed the favor of composers even at the height of polyphonic writing; unison passages spaced two octaves apart mark the unity and cohesion of the argument as in J. S. Bach's E minor Fugue (WTC I, Schmieder-Verz, 855).

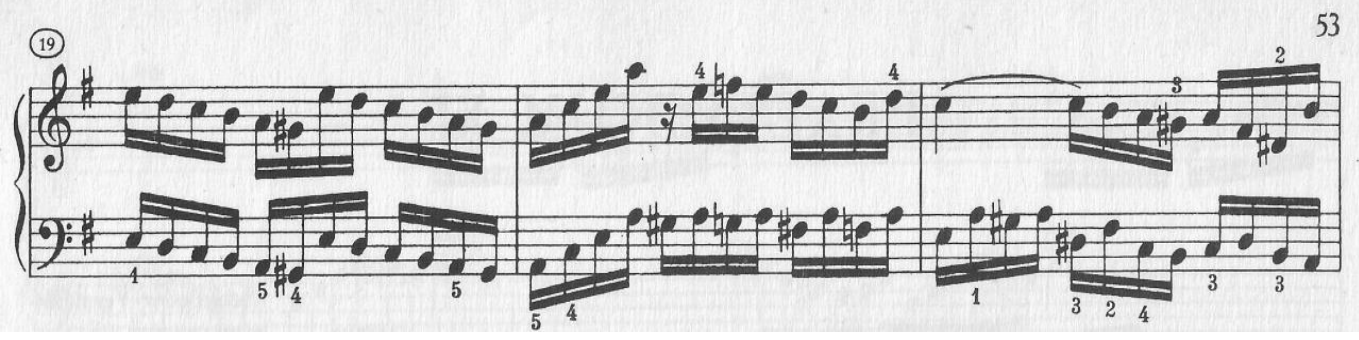

Figure 4: E minor Fugue from the Well Tempered Clavier [mm. 19-21]

Discussing the value of unity and variety in composition, Bonds affirms "multiple things [are] parts of a single thing. [Unity] arises from a connection between parts that dissuades us from seeing anything other than a single entity". Furthermore, the author asserts that "Unity, then, is the cause of perfection and beauty...". As a simple straightforward device, which renders the narrative unencumbered by conflicting tones, Bonds maintains this perspective as he discusses the unison as "essentially a rhetorical motivation behind the structure" ${ }^{\prime \prime}$.

The unison has been effectively used as a point of convergence, a compositional nexus. Beethoven's indebtedness to Haydn, Mozart, Clementi and a host of prominent composers has been well documented. In a previous study, ${ }^{41}$ some well-known unison passages have been recognized as shared elements from one Sonata to another, traversing generations. A case in point, Stravinsky's 1924 Piano Sonata (Fig. 5), is among the works analyzed by Hindemith in the third part of his Craft. In his words: "The analysis of the opening of this work produces such simple results that it seems unnecessary to add any explanation. (Hindemith 1937, p. 216).

\footnotetext{
40 Bonds, Mark Evan. op. cit, p. 138.

41 Gerling, Cristina C. 2006 (May). A Sonata para Piano de José Alberto Kaplan e a Tradição da Escrita Pianística. Claves, I. p. 73-90.
} 


\section{COHATA}

\section{SONATE}

1

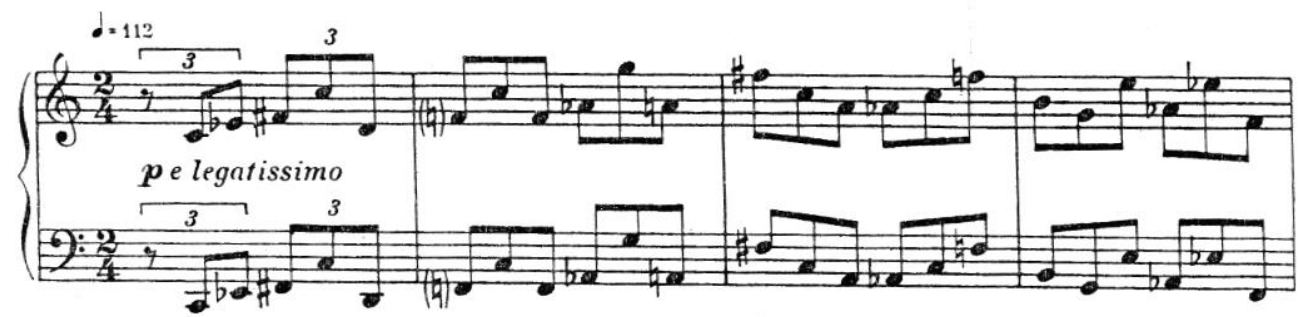

Figure 5: Stravinsky's Piano Sonata (1924) [mm. 1-4]

The 'simple results' were not missed by the composer as attested by the employment of a two octave apart unison figuration ${ }^{42}$ in the opening of the Second Movement of his Second of Three Piano Sonatas of 1936 (Fig. 6). In addition, while extensively discussing acoustics, the overtone series, scale formation and basic chord formation, Hindemith ascribes the highest generating power of resonance to the octave, the resulting interval maintained throughout the sounding of the unison figure.

II

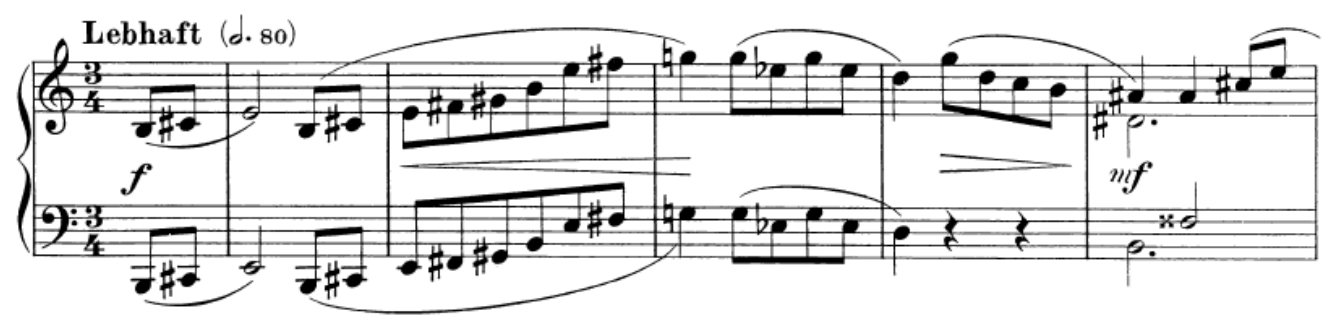

Figure 6: Hindemith's Second Piano Sonata, second movement [mm. 1-5]

The interpretation of the use of unison figurations found in Santoro's two sonatas, CS 3 and CS 4, is compatible with the presentation of tragic heroes. Following this line of thought, the tone is exalted and the resulting music is as dignified and it is grandiose. Taking the Allegro energico as a cue from his predecessor and former employer's Sonata Breve43, CS 3 articulates the

\footnotetext{
42 Two, three and four octave unison figurations are also very prevalent in chamber music, see for instance Prokofiev's F minor violin and piano Sonata op. 80 (1938-1942).

${ }^{43}$ Prior to 1948, the year Santoro went to France, he worked at Conservatório Brasileiro de Música owned by Lorenzo Fernandez. See Santoro, Maria Carlota Braga. 2002. Resgatando Memórias de Claudio Santoro. Rio de Janeiro: Barroso.
} 
presentation of the theme spaced two octaves apart and striking the downbeat before proceeding in a straightforward manner. The rhythmic figuration is powered by sixteenth notes interrupted by short sixteenth rests calling attention to the twice-enunciated downward movement Eb-Db-C-B [mm.1-2]. Once the chromatic descending movement is completed, that is, the interval of the fourth is fulfilled as it reaches $\mathrm{Bb}$ (Eb-Db-C-B-Bb, [m.3]), the forward impulse of sixteenth notes gains a new momentum, the unimpeded hero strives forth. The motivic reiteration counteracts these brief interruptions and provides the necessary determination to continue with a march marked by dynamic contrast $(f p)$ and quasi-regular alternations between black and white key segments.

The harmonic field is one of oscillation between chords used for color rather than function. The repeated climbing fourths not only infuse the initial presentation of CS 3 [mm.1-17], not seen in the next example] of the theme complex; it also dominates the entire movement. Throughout CS 3, the most monomotivic of all Sonatas here discussed, sections are delineated by changes in texture and mood rather than musical material. This is a 'Promethean' work, the composer will maintain the primacy of the motivic fourths throughout successive repetitions thus generating insistence close to despair (Fig. 7).

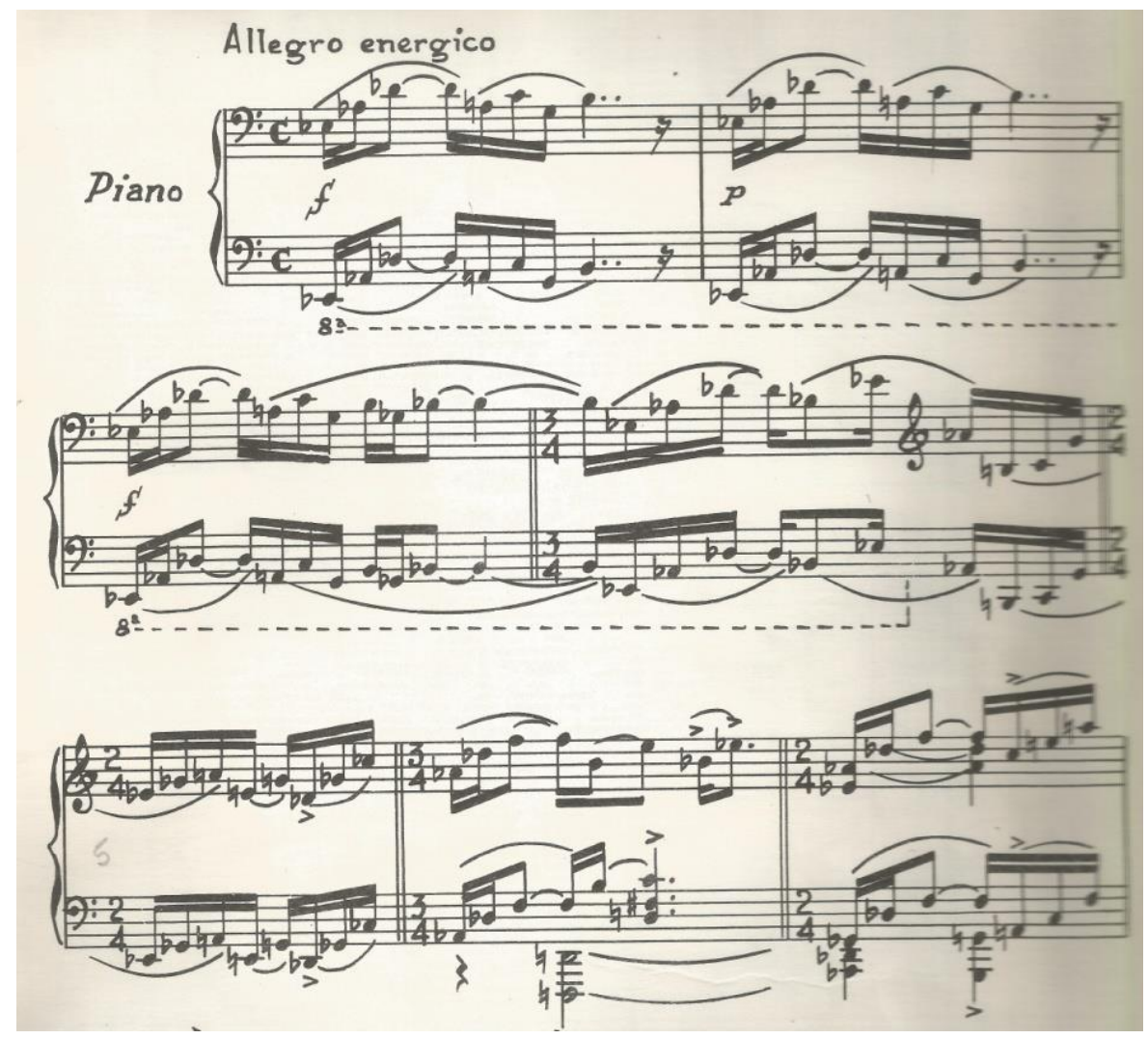

Figure 7: Claudio Santoro, Third Piano Sonata, opening measures [mm. 1-7] 
As seen in the next example (Fig. 8), CS 4 [mm. 1-16] is also based on the repetition of motifs and it too presents sixteenth note figurations in unison two octaves apart and placed at the lower to mid-range of the keyboard. The angularity of the intervals and the insistence on the repetitions are, nevertheless, more pressing in CS 3 and less so at CS 4 . In spite of the warning deciso, motivic events are placed further apart and mediated by slower moving chords. As in the CS 3, chords provide color and support for the rapidly moving figuration in unison. The two-octave space between the hands is kept throughout this presentation supported by cluster-like undulating sonorities.

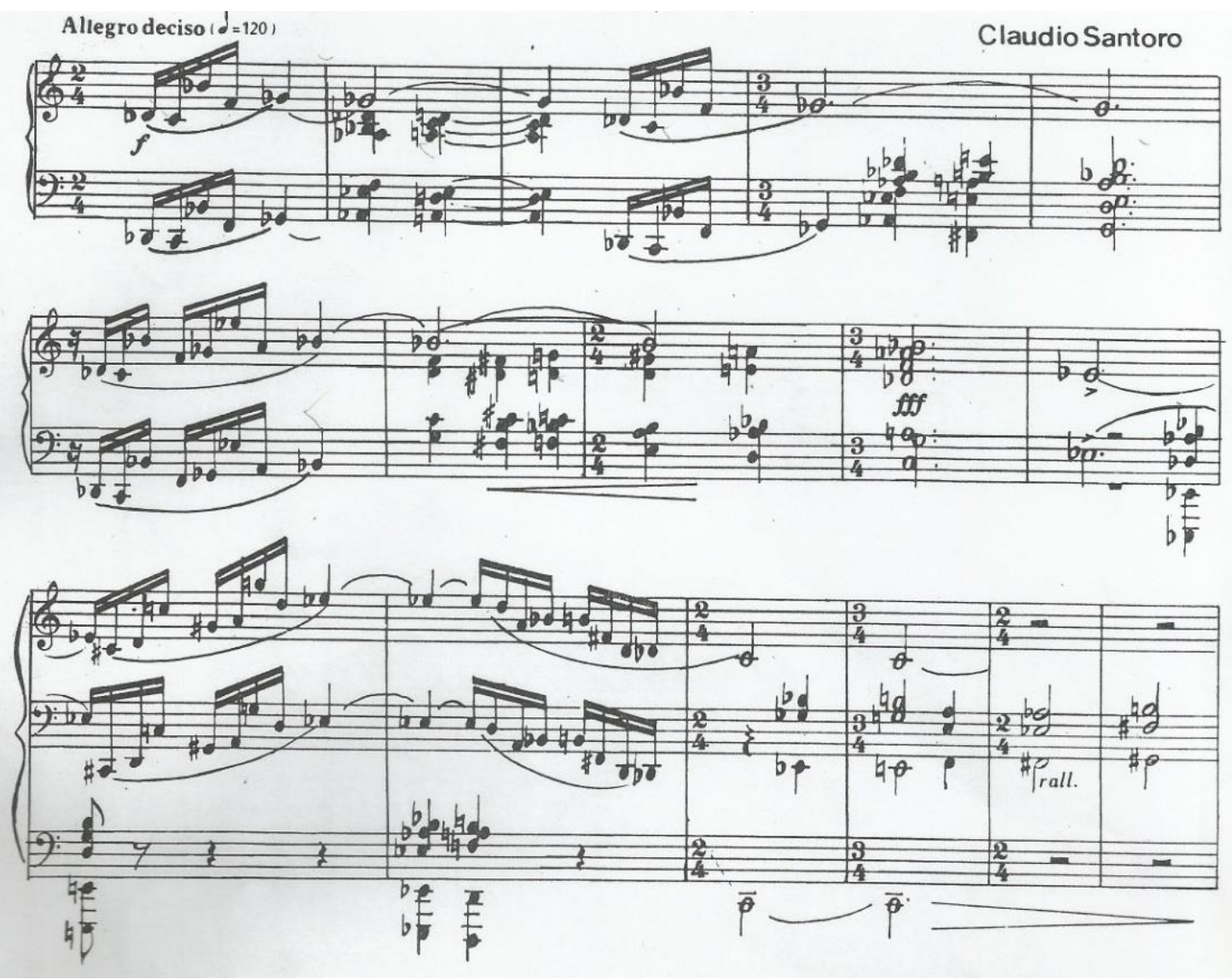

Figure 8: Claudio Santoro, Fourth Piano Sonata [mm. 1-16]

Contrasting with the opening of CS 3, the oscillating harmonies of CS 4 provide a background sonority against which the sixteen note undulating figurations assert their primacy (Fig. 8). Here too I evoke the notion of gesture as a concept that allows the crossing of the traditional boundaries between the physical and the mental worlds, between bodily sensations and musical imagination. At this injunction, I address a key issue, that is, the role of the pianist as the narrator of musical meaning, the mediator between the written score and 
the sound results. As such, I rehearse musical gestures combined with physical movement and sound as I play the first events of these works, or to use Hatten's words, I use gesture as the basic element of "significant energetic shaping through time" 44 .

Contrasting to the monomotivic CS 3, CS 4 leaves the lower register of the piano and moves on to lighter grounds by presenting a parodic contrasting march [m. 17], the unison/hero leaves the stage for a while. CS 3 and CS 4 first theme/heroes both shun any signs of identification with national characteristics only to present last movements exuding national fervor.

Scliar's Piano Sonata also brings out a decisive character (Fig. 9), the writing itself requires playing with forward motion, determination and resolve, a feat achieved through the combination of musical and physical gestures. As is the case of the works here discussed, ES also displays a marked predilection for fourths both as melodic and harmonic entities. The work starts as a single voice [m. 1] and the initial interval of the perfect fourth comes preceded by a rest, the theme pauses briefly before striding forth in its quest. The rest followed by figures of longer value confers forward momentum to the ensuing march. The one-octave spaced unison figurations [m. 2] and [m. 5-6] help set a solemn mood prevalent throughout the movement. Scliar masterfully anchors the left hand slower moving and supporting figure on quartal harmonies [m. 3-4]. These same initial measures greet the analyst with transposed and augmented segments at differing speeds while demanding varied articulations from the pianist in order to realize the contrasting sonorities. Scliar shapes her hero one dimension at a time; she does not shy away from presenting a theme/hero as serious, reserved and determined ${ }^{45}$. After years of personal and compositional struggle ${ }^{46}$, the resultant sonata is a work of love, experience and resolve; it is a well- developed presentation of a dramatic musical composition.

44 Hatten, Robert S. 2004. Interpreting Musical Gestures, Topics, and Tropes: Mozart, Beethoven, Schubert. Bloomington: Indiana University Press.

45 The idea of unison becomes more significant as the Sonata unfurls. It comprises an extended section at the very middle of the second movement [ $\mathrm{mm}$. 59-80] as if to form an arch to the entire composition, and it returns in retrograde at the end of the third and last movement [mm. 235238].

46 Holanda, Joana Cunha de. 2006. "Eunice Catunda (1915-1990) e Esther Scliar (1926-1978): trajetórias individuais e análise de "Sonata de Louvação" (1960) e "Sonata para Piano" (1961)". Doctoral Dissertation. UFRGS. 


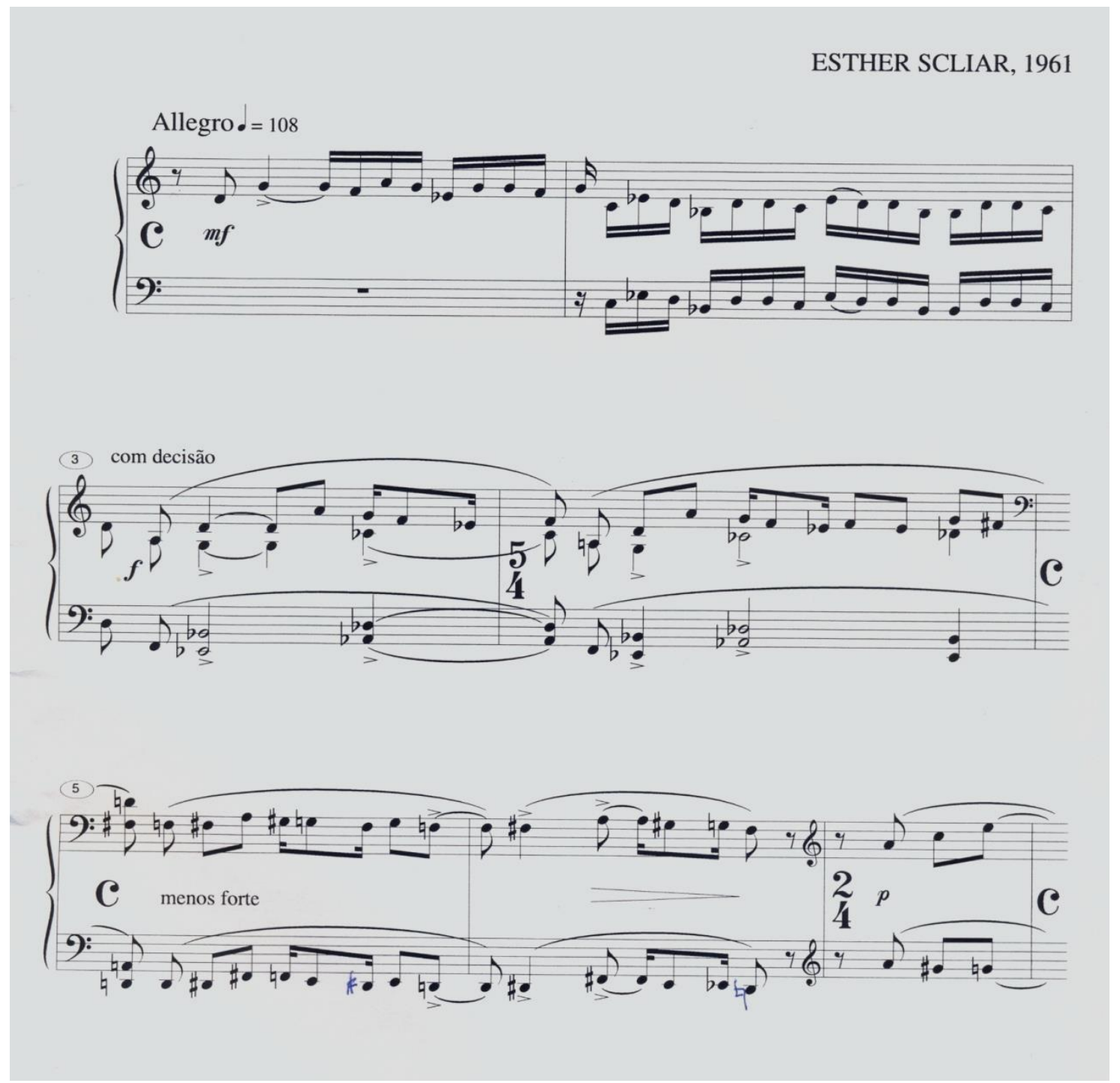

Figure 9: Ester Scliar, Piano Sonata (1961)

The initial ascending fourths confer an angular nature to CS 3, CS 4 and ES (Figs. 7, 8, 9) in a way that the ensuing narratives are set in motion with utmost decision and seriousness ${ }^{47}$.

The opening of Catunda's Sonata de Louvação, EC, is brilliant and sensual (see fig. 10). Considering the keyboard disposition of the low Eb chord on the left hand [m. 1], the high register placement of the right hand figuration and Catunda's own writings ${ }^{48}$ on the subject, Iemanjá arises from the sea and commands this dazzling display of pianism. Again, I call attention to the role assigned to the unison; through a series of arpeggiated figurations, the Goddess

\footnotetext{
47 As she was writing her own Sonata, winner of a first prize in composition (MEC, 1961), Scliar frequently relied on Krieger's guidance. (Holanda, op. cited. p.175).

${ }^{48}$ Kater, Carlos. 2001b. Eunice Catunda - Musicista Brasileira. São Paulo: Annablume.
} 
reveals herself in all her glory in order to impart her blessings on her adoring subjects, the strongly resonant chorus. I also invite the reader to hear the downward sequence $\mathrm{Eb}, \mathrm{Bb}, \mathrm{F}, \mathrm{C}$ and the return to the $\mathrm{Eb}$ one octave below. The prevalence of the octave subdivided into two tetrachords $\mathrm{s}^{49}$, and articulated by the pianistic figuration in descending unison lines is inherent to the thematic construction. Coincidence or not, Stravinsky's Piano Sonata and Hindemith's Ludus Tonalis were part of Catunda's formidable piano repertoire ${ }^{50}$. I can think of a precedent for this kind of magnificent piano writing in the works Liszt's Transcendental Etudes and Mignone's Lendas Sertanejas. Similarities however are short lived, Catunda's Sonata is a mighty goddess dressed up as Eb, her use of diatonic, consonant sonorities sound downright conservative and disconcertingly archaic but she takes the plunge, her Goddess's convolutions and motivic repetitions are worth the risk.

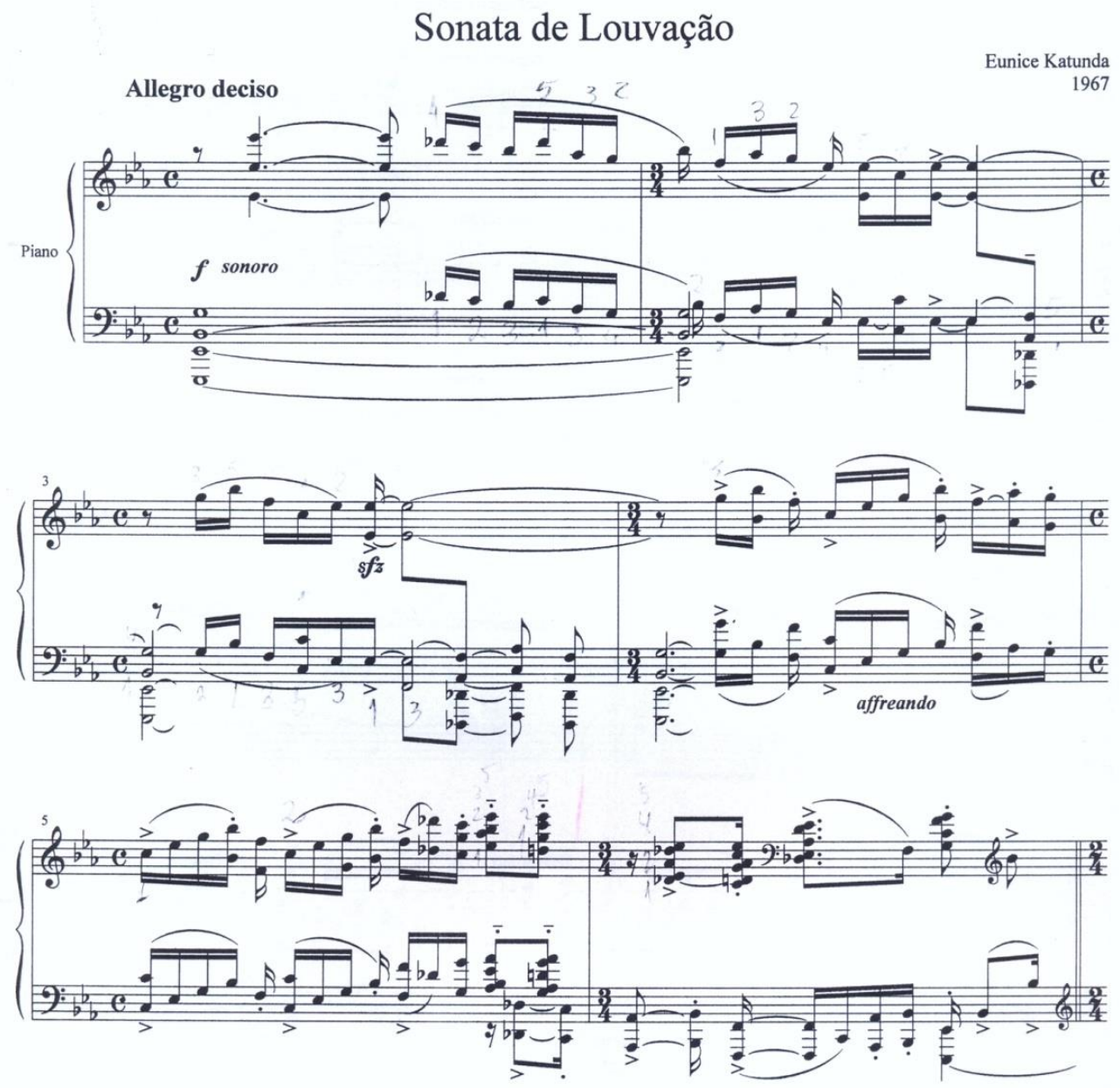

Figure 10: Eunice Katunda's Piano Sonata

\footnotetext{
${ }^{49}$ Livero de Souza, op. cit., p. 181

${ }^{50}$ Kater, 2001b, op. cit., p. 37.
} 
EC's theme, although softened by downward winding lines and strong tonal content, is the most majestic of them all in its embrace of the full extent of the keyboard. There is a strong sense of communion between the supporting crowds- the earthly low register, the congregation humming the lower sounding chords, and the radiant singing of Iemanjá on the higher registers. The composer commands the potentialities of her instrument with the full rhetorical force of her musical discourse.

As seen in the next figure (Fig.11), decision, energy and liveliness are heroic virtues praised in epic literature of all times, as much as characterizations of sonata-allegro compositions. The unison, the hero's voice in its pure state is heard as the dramatic persona of the composition; it may be supported but not contested.

\begin{tabular}{|c|c|}
\hline CS 3 1954-55 & Allegro energico \\
\hline CS 4 1957-58 & Allegro deciso \\
\hline EC 1958 (revised 1968) & Allegro deciso \\
\hline ES 1961 & Allegro (com decisão) \\
\hline
\end{tabular}

Figure 11: Indication of tempo and character

The attraction to compose march-like movements with decision and energy is a commonality shared by Santoro, Catunda and Scliar (see Fig. 11). While CS 3 and CS 4, ES and EC illustrate March types imposing authority to the listener as the dramatic content of the discourse unfolds, ES also displays affinities with some sort of Sturm und Drang spirit through her intense, combination of diatonic, both Myxolydian and Major modes, with chromatic turns and impassioned style of declamation.

These sonata openings demonstrate a predilection for downbeat beginnings and clear-cut figurations empowered by sequences of sixteenth notes. By dint of unisons mingled with imitations, inversions and other means of melodic/rhythmic elaborations associated with western classical music, ES and EC fall within the category of high style, international, ceremonial and marked. ${ }^{51}$ As part of the neoclassical frame, the works stride through a series of continuous propulsive events even though the rate is never frenzied. The theme complexes are presented in a majestic manner; there is an element of resolve, dignity and solemnity ${ }^{52}$ that borders on the kind of order displayed on military parades

${ }^{51}$ Salles. Paulo de Tarso. 2016. Compilation of styles and topics. Oral presentation at ARLACIMS, Santiago de Chile (with the author's permission).

${ }^{52}$ Terms found in the description of High Style according to Scheibe's in: Leonard Ratner. 1980. Classic Music. Expression, Form, and Style. New York: Schirmer Books, p. 7. 
honoring national holidays ${ }^{53}$.

Not all heroes are made equal; tales about reluctant heroes are as frequent as tales of heroes in disguise. EK 2's theme/hero presents itself by articulating a melancholic, almost reserved arpeggio figuration built on ascending and descending lines centered on F\# [m. 1]. As seen in Fig. 12, the $m f$ utterance [m. 1] is soon interrupted by a long meandering commentary, a diversion from the initial resolve as if the hero/theme had not yet decided on a path. Between the two unison passages, echoes of melodies supported by thirds ending in trills constitute a classical gesture revisited from Krieger's First Sonata. At m. 12, the theme/hero finds the right key, G [m. 13] a longer passage confirms the importance of the unison [mm. 9-13] as the protagonist moves towards the cadence on G [14]. The presentation of the unison figuration in EK 2 enters into a dialogue with works from times past such as Haydn (HOB: XVI-32 C\# minor) and Beethoven (op. 57 in F). From this last work, the reminiscence of a unison figuration returning a half step up is particularly significant (m. 11) as it imparts a nostalgic mood for the entire passage [mm. 1-13].

${ }^{53}$ Matta, Roberto da. 1983. 4th ed. Carnavais, Malandros e Heróis- Para uma Sociologia do Dilema Brasileiro. Rio de Janeiro: Zahar. 


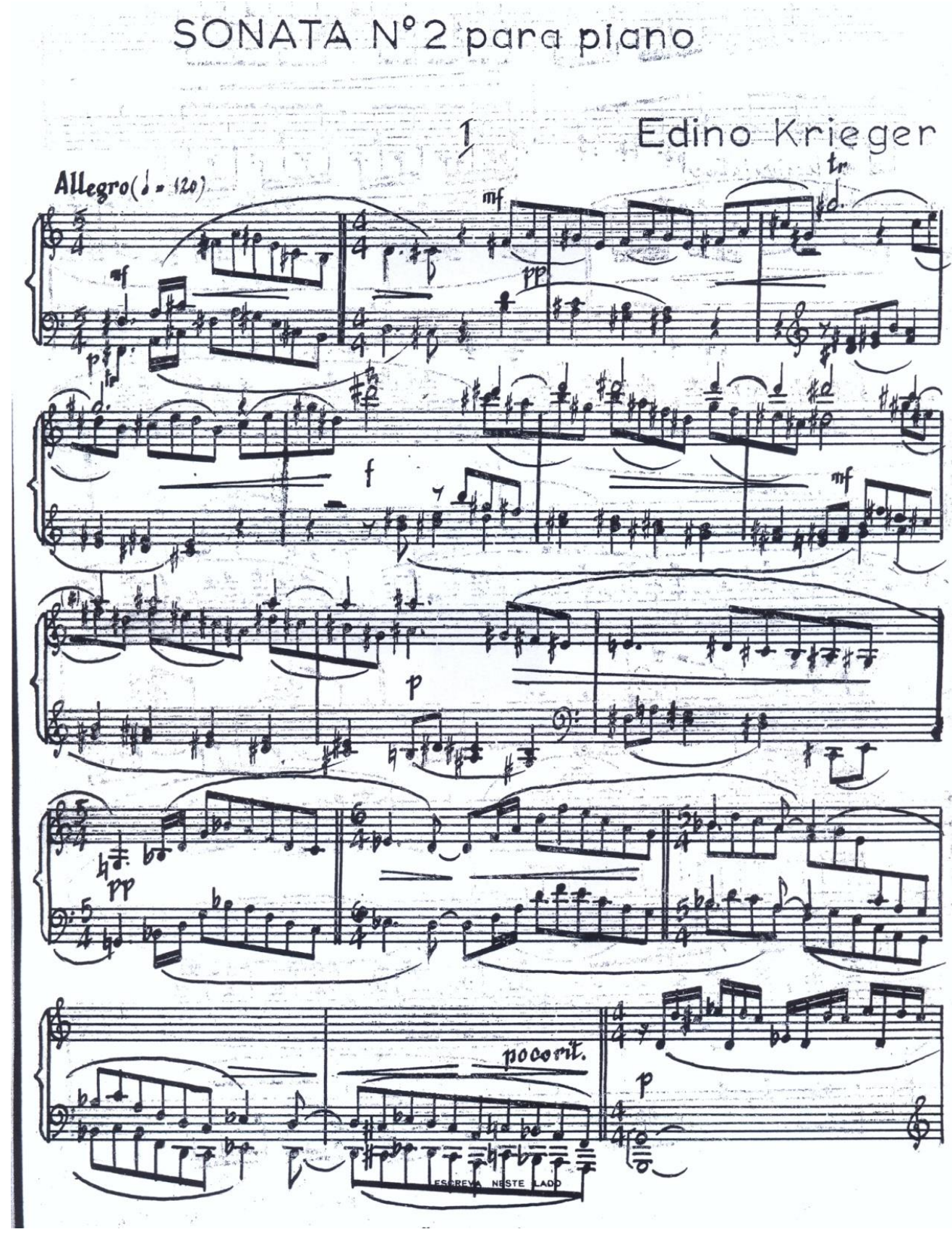

Figure 12: Krieger's Second Piano Sonata [mm. 1-17]

Before proceeding, it is essential to consider that the five works so far mentioned sound heroic but not particularly imbued with specific elements originating from national character. On the contrary, composers have striven to ascertain the paternal ascendency from European provenance and to develop a musical decorum akin to a higher style ${ }^{54}$ of learned counterpoint and motivic elaboration. Let's keep this in mind as the contrast with the following work

${ }^{54}$ Ratner, op. cit., p. 7. 
becomes quite apparent. CS 3, CS 4, ES, EC and EK 2 heroes are not preceded by any kind of Introduction, not even an upbeat. They spring into action fully garbed and armored on the down-beat, or shortly after as is the case of ES. Utterances are delivered with eloquence albeit in a straightforward manner through the repetition of elaborated motivic patterns. In fact, it would be difficult to pinpoint to specific Brazilian characteristics as full participants of these initial presentation. With a minimum of syncopation and no more than insinuations to dance patterns, these hero types are identified with an international way of musical writing marked by strict adherence to highly structured rules of composing. EK 2 retains a ceremonial composure even though its tone is overcast and reminiscent.

Epic grandeur is likewise very ingrained at Guerra-Peixe's Vivace (GP 2, fig 3, middle column), the composer constructs one large scale scenery set in motion by a relentless ostinato figure. This Sonata presents the longest opening idea, persistent in its percussive ostinato and clearly referential to a ritual dance practiced by a minority group- a celebration of Xangô ${ }^{55}$. As seen in Fig. 13, this presentation is characterized by an absence of syncopation and a marked presence of metrical clarity thus setting this grandiose work in native Brazilian territory. The omnipresent ostinato figuration centered on the doubling of the octave packed with fourths and fifths carries the dance like figuration. While the opening phrases of the previous sonatas so far discussed expose a heroic, dramatic countenance, GP 2 displays a ritualized dance ceremonial in character, the combination of low style ${ }^{56}$, native Brazilian (indigenous), diatonic with occasional chromatic inflexions, strongly metric and only secondarily syncopated ${ }^{57}$. This work- an outburst of emotional power, also displays a hierarchical structure, the lower register carries the unrelenting percussion and the right hand, the upper voice spread over three note sonorities and with longer values sets the melodic tone. Soon the undercurrents from a third voice inserted underneath the upper voice [8] start gaining momentum, by $\mathrm{m} .11$ this new voice constitutes a counterpoint to the ostinato with such fierceness that by [31] all voices are finally united into a unison.

\footnotetext{
${ }^{55}$ An explanation concerning Xangô and the percussion instruments and percussive patterns can be found in Botelho, op. cit., p. 216-217.

${ }^{56}$ Ratner, op. cit. p.7.

57 Salles. Paulo de Tarso. 2016. Compilation of styles and topics. Oral presentation at ARLACIMS, Santiago de Chile (with the author's permission).
} 


\section{Para Maria Aparecida Ferreira}

SONATA $\mathbf{N}^{\circ} \mathbf{2}$

(para piano)

\section{César Guerra-Peixe}

- I -

$(1967)$
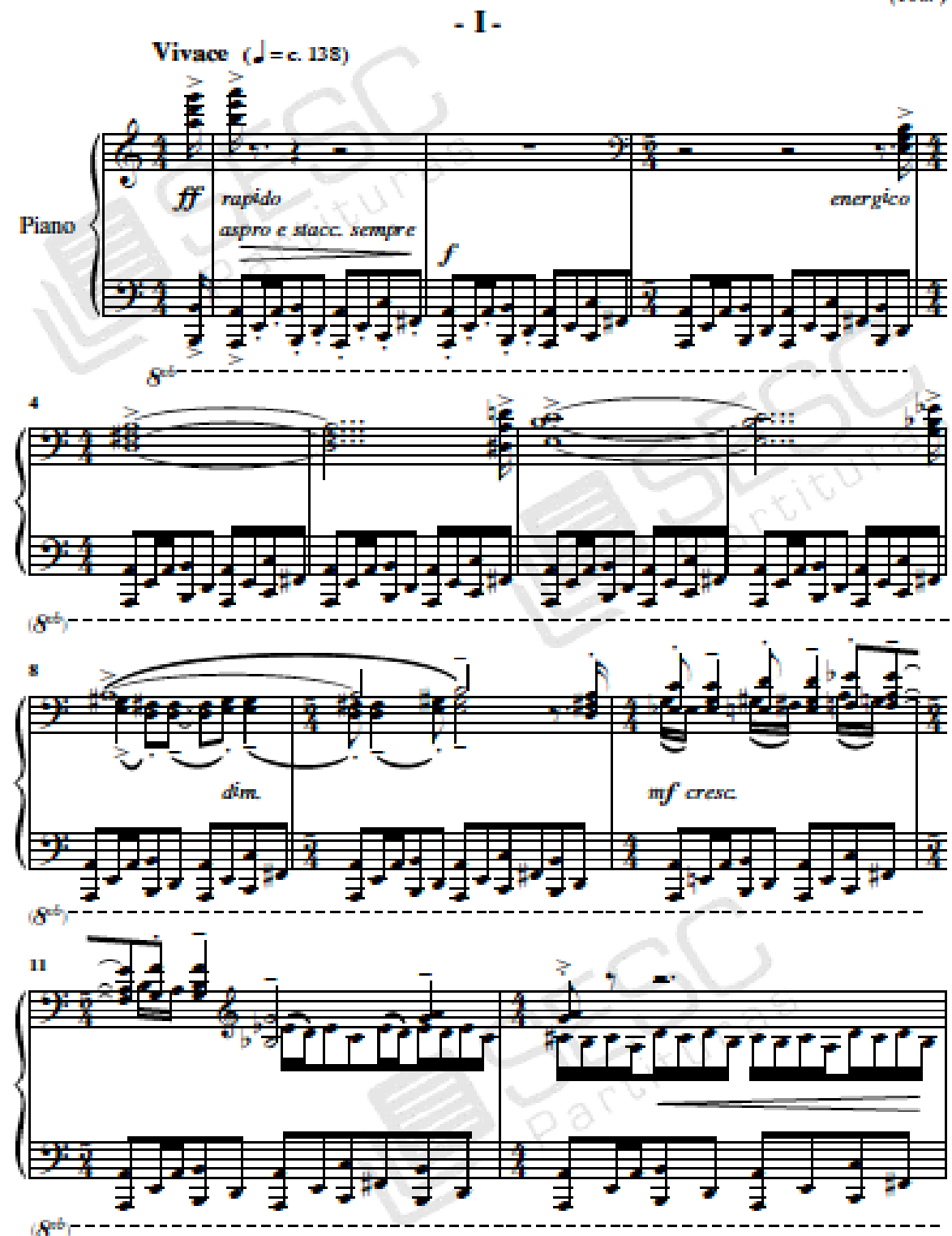

Figure 13: Guerra-Peixe's Second Piano Sonata [mm. 1-12]

GP 2's theme complex expresses an outburst of collective emotion controlled by the lower voices, then gradually by the middle voices until it explodes and coalesces [m. 31], the middle voice gradually loses its energy [mm.31-36], the beginning idea returns only to be succeeded by the secondary lyrical idea [m. 45]. In its ritualistic stride, it narrates the collective effort of a whole nation united against an oppressor (see Fig. 14). The bass line ostinato figure- people dancing to relentless pattern- is counterpointed by piercing cries 
[mm. 1, 3-4, 6-7], there is no single hero and the pianist must control the crowd by taking over the full extension of the keyboard. Opposite to the orderly military parade, the Brazilian nation subjugated by the military coup, takes over the streets to celebrate a religious cult of African origin. This seems a reasonable argument to place this work in a different category from the first five sonatas. Tragic heroes stand out as highly individualized characters as heard in five of the works previously discussed whereas GP 2 commands a whole group of people united for the performance of a ritual dance. Just as organized as a Carnaval parade, the opening theme complexes requires playing with a deliberate, dignified, objective tone and, above all with very clear diction. GP 2's savage ostinato figure is film music; it is music for action, ritualistic and grandiose (see Fig. 13).

Four of the six Sonatas begin with powerful invocations, and five display prominent unison/theme complexes calling for proper gestures in order to convey solemnity, determination and/or inevitability. GP 2 confers solemnity and ritual not by unison, parsimoniously applied at [mm. 31-32, 45, 48-49] Exposition section - but by relentless insistence on the ostinato figure. This figure itself is based on the doubling of the octave, Hindemith's pillar around which all other sonorities gravitate.

So far, the opening measures of these six works articulate the exploits welldefined thematic complexes based on motivic elaborations that, by dint of expert maneuvers and manipulations, combine instrumental abilities and compositional feats of epic proportions. This characterization, particularly apt for CS 3, CS 4, EC and GP 2, is reinforced by the fact that actions take place over the vast setting of the keyboard and cover wide ranges of instrumental space. CS 3 , CS 4, and EC favor the space afforded by the two-octave space hand placement of Beethovenian provenance, an inventive way to obtain optimum resonance from the instrument.

Playing the parts of heroes, goddesses, dancing crowds and whatever else is expected of her, the pianist is able to perform highly coordinated movements encompassing the whole of the keyboard and frequently applying surprise tactics as well as surviving dangerous maneuvers. Considering the emphasis placed on one, two and whole keyboard octave spacing in relation to the resonance afforded by the instrument, special pedal effects are part of the action that enhance the magic and do influence the intended outcome.

Having expounded my views on six of the eight works selected for this study, what of the remaining two? As in the XVIII c., Brazilian composers can devise all sorts of plots, serious and otherwise. According to the current state of my imagination, GP 1 and EK 1written in 1950 and 1953 respectively, epitomize lightness and humor in music (See Figures 14 and 15). In both sonatas, the hero's maternal ascendency takes over; two voice contrapuntal sequences convey 
touches of satire, romance and prose. While GP 1 deals with respectful discord and teasing, EK 1 progresses by two voices, taking polite turns in remarkable concord. EK1 is also somewhat nostalgic in spite of the constant moving of the broken figures and the stress on the mildly dissonant side of the harmony.

GP 1 is hybrid in more than one dimension. Given its contrapuntal and imitative nature, it belongs with the "learned style" despite of the fact it depicts a duel between a laid back rural "toada" and a livelier "embolada" 58 . Conversely, the melody takes precedence over the left hand part in such way that the pianist is bound to adopt a deep singing tone, perhaps a blind man's prayer with its nasal twang sounding against the background retorting of a rhythmic ensemble nearby.

\section{Para Jeannelle e Heitor Alimonda \\ SONATA $\mathbf{N}^{\circ} \mathbf{1}$ \\ (para piano)}

- I -
César Guerra-Peixe
(1950)
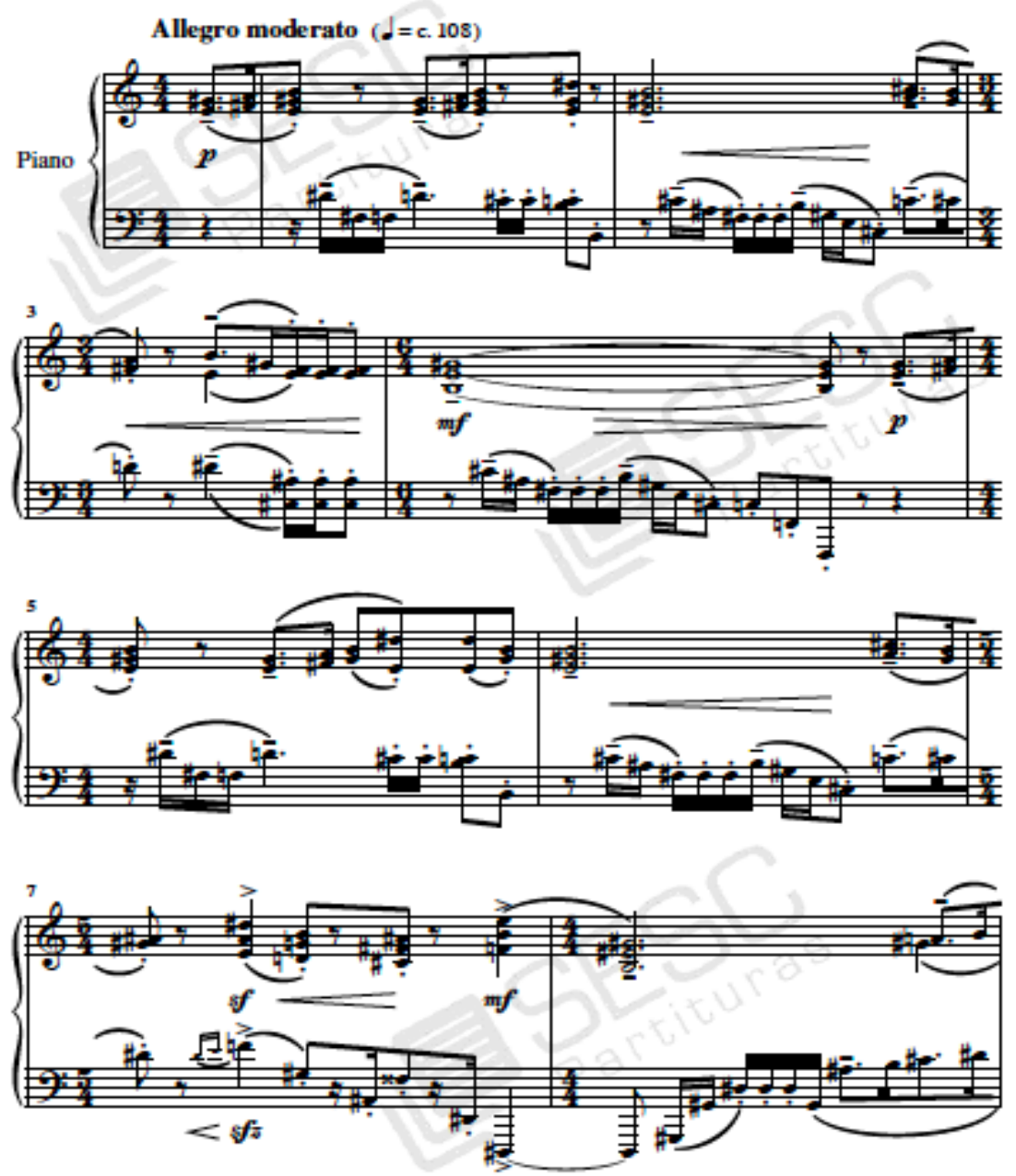

Figure 14: Guerra-Peixe's First Piano Sonata [mm. 1-8]

${ }^{58}$ Pereira Botelho, op. cit. p. 140-141. 
GP 1's double thirds are round and unabashedly naïve even though his choice of chords is not a conventional one. GP 1 presents a quaint hero, the E Major triad rising towards its major seventh (D\# at mm. 2, 5, 7) and playing a naïve tune counterpointed by a faster moving and mostly contrary motion left hand. GP 1 is rural, wistful and full of song. The melody is plain and unencumbered as befits the allusion to folk song; the tone is modest and reconciled to its fate. The arching E major triad exudes a feeling of resigned tranquility, this triadic figure naiveté is contrasted by a chromatic retorting left hand, the counterpoint offers snappy commentaries to the melody; together the musical lines are, as plainly intended by the composer, strongly reminiscent of the Brazilian Northeast. Moreover, Guerra-Peixe uses the piano but his music depicts a folk ensemble. The accordion is the hero; the guitar and the percussion are the supporting cast. This First Sonata fits within Guerra-Peixe's search for communicability [comunicabilidade] ${ }^{59}$ in the sense proposed by Mario de Andrade's admonitions. Albeit not nearly as dictatorial, Andrade's writings had strong points of contact with the Socialist Realism musical doctrine propagated by the Soviet government. Guarnieri's momentous Open Letter of 1950 addresses the very same concerns, namely to keep young composers away from pernicious tendencies of experimentalism - dodecaphonism, while pleading in favor of the adoption of 'Brazilian culture' - the use of folk elements ${ }^{60}$. Guerra-Peixe was already in compliance with Guarnieri's pleas before the ink of the famous letter ${ }^{61}$ had dried. He was also very eager to demonstrate he knew more about popular and folk Brazilian music than any other Brazilian composer did and this first sonata is his way of proving his claim.

The hero of EK 1 with its mix of melodic thirds, fourths and occasional sevenths resulting from the succession of seventh chords also present in the most prevalent genre of popular music of the time, Samba-Canção (see Fig. 15). This sonata reveals the quintessential carioca type who, with the support of a romantic pair, [left hand] displays an unsurpassed amount of elegance, a rascal [malandro] charming his way in and out of varying chordal colorings. In addition to providing color, the sequences of arpeggiated seventh chords surfing the keyboard also bring out the motivic content of this first idea. Krieger's hero is urban and sophisticated, the consummate soft spoken rogue able to weave a humorous tale with the rules of two voice imitative florid counterpoint. Contrary to EK 2 but pointing to a sophisticated dialogue between works, trills precede the accompanying thirds [mm. 2-3, 5-6] of EK 1 . Preceded by a short upbeat, and, given its wealth of contrapuntal expansion, EK 1 looks international on paper

\footnotetext{
${ }^{59}$ Barros. F. M., op. cited.

60 The Sonata precedes the famous open letter by at least five months; it was completed by July 1950. See Neves, José Maria. 1977. Música Contemporânea Brasileira. São Paulo: Ricordi, p. 116.

${ }^{61}$ Camargo Guarnieri, “Carta Aberta aos Músicos e Críticos do Brasil”, published November 1950.
} 
and sounds downright "carioca" to the ear. The pace of EK 1 is fluid and the mood pleasant. It is lively without any trace of anxiety; a hint of melancholy furnishes just the right amount of elegance. It anticipates Bossa Nova by a few years as the figures in alternation create an effortless albeit characteristic "ginga" ${ }^{2}$. As the sidewalk in Copacabana, motion is created by the soft waves of arpeggios moving seamlessly towards the next beat.

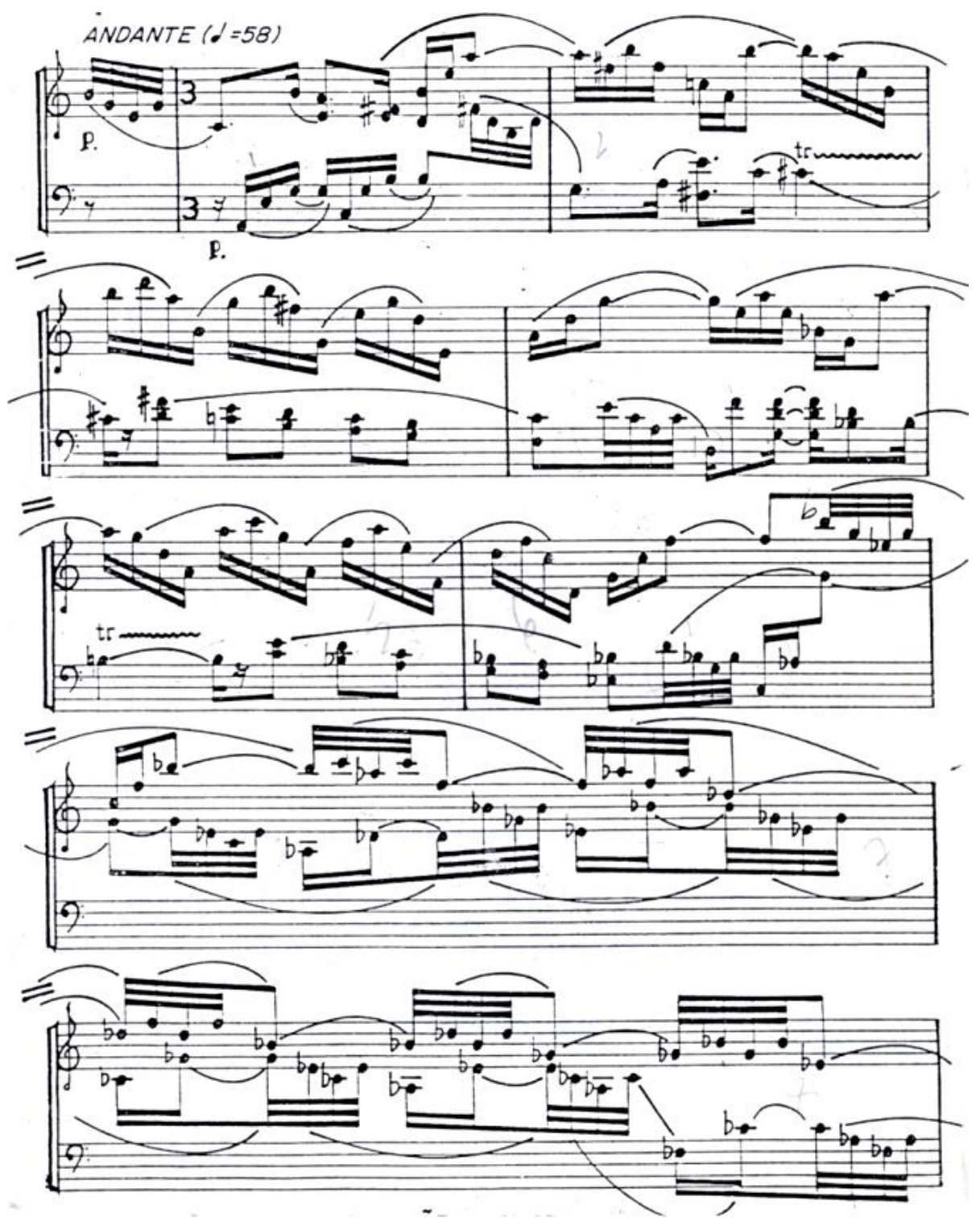

Figure 15: Edino Krieger's Sonata $n^{\circ} 1$ para piano [mm. 1-8]

As is the case of GP 2, unison figurations are absent at the opening measures of both GP 1 and EK 1. GP 1 displays short passages in unison as a

${ }^{62}$ Ginga refers to the swaying of hip and feet movement characteristic of Brazilian dances. 
resting point (for instance [m. 13]) out of which further elaborations in contrary and/or parallel motion spring forth (Fig. 16).

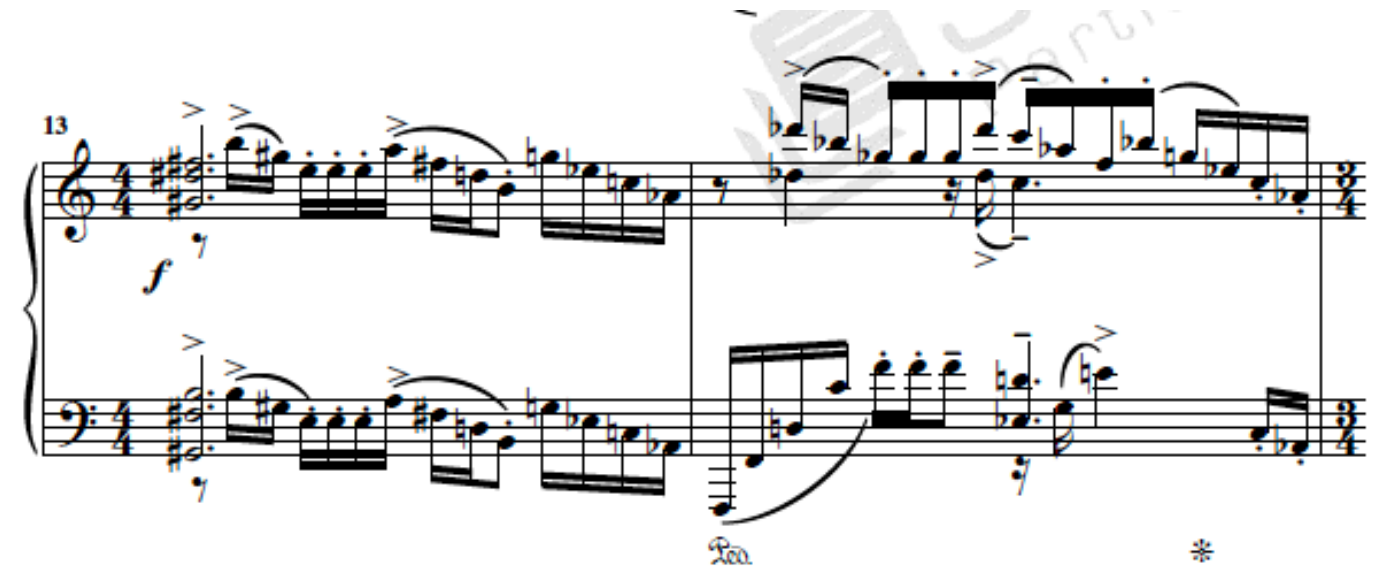

Figure 16: Guerra-Peixe's First Piano Sonata [mm. 13-14]

As exemplified in Fig. 16, Guerra-Peixe seldom uses unison figurations in this particular movement. In this respect [m. 13] is almost an exception, whereas Krieger resorts to more extensive unison figurations once the theme is fully presented. EK 1, after exploring various modes of imitation, reintroduces the theme in unison as a compositional variant (Fig. 17).
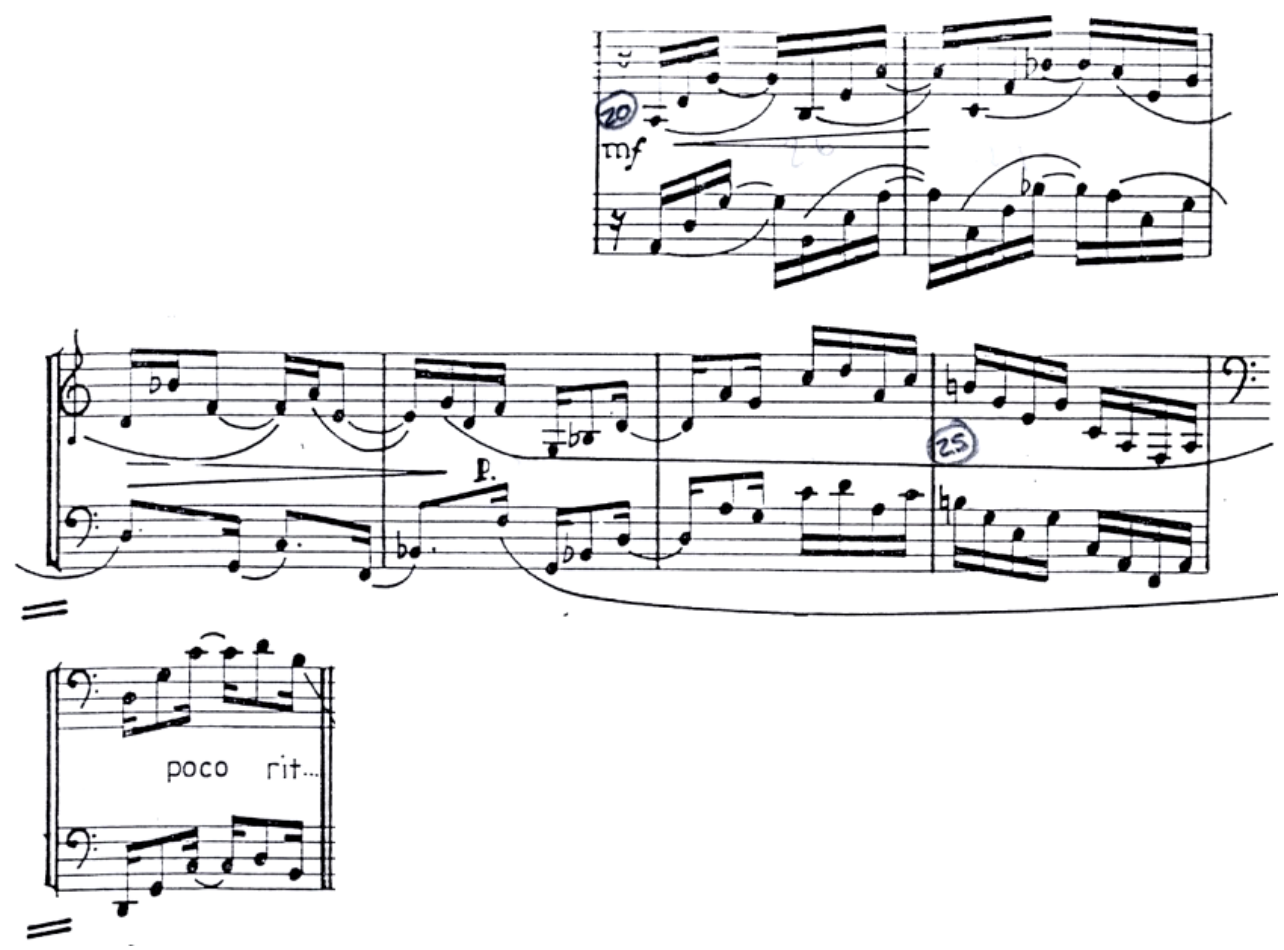

Figure 17: Edino Krieger's First Piano Sonata, unison passage [mm. 20-25] 
GP1 and EK 1 move to a slower beat, the pace of the narrative is amenable albeit no less inventive; their affable character points towards a lighter vein. Right and left hands sing and dance carefully interlaced contrapuntal lines in a most cordial manner. As the first piano sonatas of each composer, these works display some quintessential Brazilian traits, Guerra-Peixe with Northeast topics and Krieger with the harmonic environment of Brazilian urban music, notably that of Rio de Janeiro. In the case of EK 1, the pianistic writing is made to sound like a highly skilled improvisation while GP 1 manages to accommodate, as previously mentioned, two different songs opposing each other.

As far as the composing of sonatas is concerned, once thematic patterns are defined musical discourses rarely wander far from the initial sources. CS 3 tenaciously adheres to its motivic configuration throughout the entire first movement. ES, through feats of melodic augmentations and diminutions, replicates the rhythmic impulse from the initial eight-note rest towards the downbeat of the next measure [mm. 1-6]. EC, conversely, replicates the rhythmic patterns but manages to go into a process of liquidation of the theme into its smaller component parts. EK 1 maintains the thematic contour as an advantageous point to explore the possibilities of registral change on the instrument while EK 2 juxtaposes seemingly contrasting material; together both ideas form an extensive arch from the lower register into the higher and back to where it had begun [mm. 1-17]. It is fair to say that, in their disciplined adherence to motivic elaboration, these beginnings contrast sharply with Villa-Lobos's compositional methods as somewhat derisively described by Guerra-Peixe ${ }^{63}$. Considering that the bulk of these works were written before and around 1959, year of Villa-Lobos' passing, a desire to surpass the revered predecessor becomes a justifiable argument. At the same time, I listen to the stories of a hopeful and energetic nation being interwoven in the musical discourse; I detect a new tradition in the making.

\section{5 - Final Remarks}

These eight works were written by composers no longer young, avid to show signs of mature musical writing and competent craftsmanship on a par with their international peers. Moreover, they shared a need to find acceptance beyond their experimental previous phases. Their time of apprenticeship under the common ground of dodecaphonic procedures may have been exhilaratingly

${ }^{63}$ See Pereira Botelho 2013, p. 82-83 as well as Guerra-Peixe's correspondence with Mozart Araújo between 1940 and1950 kept at Centro Cultural do Banco do Brasil, CCBB, Rio de Janeiro. 
daring and, as a group of young composers they had achieved a particular distinction. Nonetheless, the time for experimentation was over; a new path had to be found. How was it achieved? From a general perspective, each composer employed sonata structures as instances of contrasting ideas in succession in such way that by being repeated, insisted and elaborated, achieve higher status over other ideas that are less elaborated and/or reiterated. Moreover, each Sonata presents a clearly defined theme complex allowing for both, compositional imagination and pianistic prowess.

As a pianist, I regard musical events as characters, that is, assertive gestures that regulate the succession of musical events as fuel for my rhythmic, melodic and harmonic imagination. In this respect, I conceive plots in which these characters carry actions and an overall design is delivered. As I hope to have demonstrated, intertextual and narrative elements are combined and recombined in order to magnify the intended interpretative outcome. With this frame, my analysis encompasses imagining differing characters/heroes according to the main features presented by the theme complexes so that my body accommodates to the needs of the action being narrated. Musical narrative, as is the case of most narratives, depends on the succession of musical events in such way that absences and recurrences become not only more or less predictable but also a source of coherence. There is no point in applying the kind of information gained from formal analysis if this knowledge is not transformed into musical imagination and pianistic competency. Music making from the piano involves movement, that is, the physical displacement of an object in space in order to produce meaning- the mental activation of an experience.

The embodiment of character allied to the knowledge of the score with its repetitions, insistences, flashbacks, interruptions, and all sorts of discursive resources that contribute to heighten dramatic effect can transform an unexciting rendition into a meaningful one. Summing up, the pianist commands instrumental resources in order to produce a convincing narrative tone according to the characteristics of each work.

As these works came to light a new canon was formed, Brazilian pianists had choices where previously there were few. It is my contention that five composers adopted a narrative tone reflecting a time of profound international awareness, a language able to connote the feelings of a country in the process of acknowledging and fulfilling its destiny. I hope to have shown how a Brazilian piano repertoire was being imagined as a group project of shared ideals and individual features that distinguish each one of the authors. Collectively these works stand for the development of a tradition of piano sonata writing. By the 1960's several composers had followed suit; composers of older generation such as Francisco Mignone decided to innovate and produce experimental works bearing the title Sonata while Guarnieri finally wrote his one and only Piano 
Sonata in the early 1970's. The practice also attracted many younger composers from diverse regions of the country; a partial list of their works can be found at www.ufrgs.br/gppi.

\section{References}

1. Barros, Frederico Machado de. 2013. “César Guerra-Peixe: a Modernidade em Busca de uma Tradição". Doctoral Dissertation, USP.

2. Bloom, Harold. 1975. A Map of Misreading. New York: Oxford University Press.

3. Bonds, Mark Evan. 1991. Wordless Rhetoric, Musical Form and the Metaphor of the Oration. Cambridge: Harvard University Press.

4. Botelho, Flávia Pereira. 2013. "Guerra-Peixe e a Busca pela Renovação do Nacionalismo Musical: Reflexos na Obra para Piano". Doctoral Dissertation, USP.

5. Copland, Aaron. 1942. The Composers of South America. Modern Music.

6. Egg, André. 2005. O Grupo Música Viva e o Nacionalismo Musical. Anais do III Fórum de Pesquisa Científica em Arte, Escola de Música e Belas Artes do Paraná. Curitiba, p. 60-70.

7. Faria, Antonio Guerreiro de. 2000. Guerra-Peixe e a Estilização do Folclore. $L A M R, \mathrm{XXI}, \mathrm{n}^{\circ} 2$, p. 169-189.

8. Frye, Northrop. 1957. Anatomy of Criticism. Princeton: Princeton University Press.

9. Gerling, Cristina C. 2006 (May). A Sonata para Piano de José Alberto Kaplan e a Tradição da Escrita Pianística. Claves, I. p. 73-90.

10. Gerling, Cristina C. \& Santos, Regina A. T. 2015. As Conexões entre Música e Emoção sob Perspectivas Psicológicas, Filosóficas e Estéticas. In: Estudos sobre Motivação e Emoção em Cognição Musical. R. C. Araújo \& D. Ramos, org. UFPR, p. 13-44.

11. Godoy, Monica. 1994. “Claudio Santoro: Overview of his Piano Works and Analysis of the Fourth Piano Sonata". Doctoral Dissertation, Boston University. 
12. Hartmann, Ernesto. 2010a. Claudio Santoro e o II Congresso de Compositores Progressistas de Praga. Anais do I SIMPOM, p. 460-468.

13. 2010b. “Estética Musical e Realismo Socialista em Obras Nacionalistas para Piano de Claudio Santoro: Janelas Hermenêuticas." Doctoral Dissertation, UNIRIO.

14. Haskins, John. 1957 (Dec.). Pan Americanism in Music. Notes, XV, No.1, p. 4349.

15. Hatten, Robert S. 1991. On Narrativity in Music: Expressive Genres and Levels of Discourse in Beethoven. Indiana Theory Review, XII, p.75.

16. . 2004. Interpreting Musical Gestures, Topics, and Tropes: Mozart, Beethoven, Schubert. Bloomington: Indiana University Press.

17. Holanda, Joana Cunha de. 2006. “Eunice Catunda (1915-1990) e Esther Scliar (1926-1978): Trajetórias Individuais e Análise de "Sonata de Louvação" (1960) e "Sonata para Piano" (1961)". Doctoral Dissertation, UFRGS.

18. Hyde, Martha M. 1996 (Autumn). Neoclassic and Anachronistic Impulses in Twentieth-Century Music. Music Theory Spectrum, Vol. 18, No. 2, p. 200-235.

19. Kater, Carlos. 2001a. Música Viva e H. J. Koellreutter. Movimentos em Direção à Modernidade. São Paulo: Musa/Atravez.

20. . 2001b. Eunice Catunda - Musicista Brasileira. São Paulo:

Annablume.

21. Livero de Souza, Iracele V. A. 2006. "Louvação a Eunice: um Estudo de Análise das Obras para Piano de Eunice Catunda". Doctoral Dissertation, UNICAMP.

22. Masterson, Sarah. 2011. "Approaches to Sonata Form in Mid-TwentiethCentury American Piano Sonatas", Doctoral Dissertation. University of Connecticut.

23. Matta, Roberto da. 1983 (4th ed.). Carnavais, Malandros e Heróis - Para uma Sociologia do Dilema Brasileiro. Rio de Janeiro: Zahar. 
24. Maus, Fred Everett. 1991. Music as Narrative. Indiana Theory Review, XII, p.3-4.

25. Mathews, Jane de Hart. 1976 (Oct.). "Art and Politics in Cold War America”. The American Historical Review, Vol. 81, No. 4, p. 762-787.

26. Napolitano, Marcos. 2014. Esquerdas, Política e Cultura no Brasil (1950-1970): um Balanço Historiográfico. Revista do Instituto de Estudos Brasileiros, n. 58, p.35-50

27. Neves, José Maria. 1977. Música Contemporânea Brasileira. São Paulo: Ricordi.

28. Newman, W. S. 1972. The Sonata in the Classic Era. New York: Norton.

29. Hindemith, Paul. 1937. The Craft Of Musical Composition (Fourth Edition) Theoretical Part. English Translation by Arthur Mendel Price. Associated Music Publishers, Inc., New York Schott \& Co., Ltd., London.

30. Pollack, Howard. 1999. Aaron Copland: The Life and Work of an Uncommon Man. New York: Henry Holt and Co.

31. Santoro, Maria Carlota Braga. 2002. Resgatando Memórias de Claudio Santoro. Rio de Janeiro: Barroso.

32. Saunders, Frances Stonor. 2000. Who Paid the Piper? CIA and the Cultural Cold War. London: Granta Books.

33. Skidmore, Thomas. 1998. Uma História do Brasil. Trad. Raul Fiker. São Paulo: Paz e Terra.

34. Straus, Joseph. 1990. Remaking the Past. Music Modernism and the Influence of Tonal Tradition. Cambridge: Harvard University Press.

35. Straus, Joseph N. 1999 (Autumn). The Myth of Serial Tyranny in the 1950s and 1960s. The Musical Quarterly, Vol. 83, No. 3, p. 301-343.

36. Tacuchian, Fátima Granja. 1998. "Panamericanismo, Propaganda e Música Erudita: Estados Unidos e Brasil (1939-1948)”. Doctoral Dissertation, USP.

37. Vieira, Bruna Maria de Lima. 2005. "Sonata n.1 para Piano e Divertimento para Cordas de Edino Krieger : um Estudo Comparativo". Master's Thesis, UFRGS. 